\title{
THE SPIRIT AND TASK OF DEMOCRATIC COSMOPOLITANISM: EUROPEAN POLITICAL IDENTITY AT THE LIMITS OF TRANSNATIONAL LAW
}

\author{
Paul P Linden-Retek*
}

Summary: Motivating this article is the continuing, yet difficult hope for a Europe of democratic cosmopolitanism, for a Europe in which cosmopolitics works to continually question the terms of lingering exclusion while preserving the ideals of self-legislation and democratic authorship. In what follows, I expand the familiar criticism of Europe's democratic legitimacy gap, its democratic deficit, as a lens through which to analyse the possibility of a supranational participatory identity within the European political space. First, I describe the contemporary juridification of European politics, specifically concerning the formal legalism of the European Court of Justice, and the dangers such depoliticisation poses to the search for a cosmopolitan demos, depriving it of its solidaristic base and affective core. Second, I offer a critique of Jürgen Habermas's 'constitutional patriotism' as a viable frame in which Europeans might hope to dissolve the contradictions of a nascent constitutional democracy at the supranational level. Rather, following the work of Bonnie Honig, I develop a more primary and original paradox confronting the European Union: the 'paradox of politics', which posits the radical indeterminacy of the demos as the starting place for the creation of any political identity. Third, drawing on Ernesto Laclau's conception of hegemony, I develop in greater detail the processes of symbolic identity-formation involved in such a creation, namely the interplay of inclusion/exclusion that characterises modern political attachment. What this analysis elucidates is that the problem of EU constitutionalisation and political integration is the problem of borders or of the closed polis, in general. The apposite symbolic frame of European political identity is therefore that of 'the heterogeneous', that which constructs yet destabilises our settled understanding of boundary and border and reveals them to be contingent. In this vein, I argue that the operative European political subjects are now in a certain sense the refugees, the sans-papiers, and the third-country nationals, each of whom serves to remind EU citizens of this foundational contingency of existing legal orders. Practically, I analyse European citizenship and immigration laws within

* PhD student, Department of Political Science, Yale University; Harvard University, AB 2008; Yale Law School, JD 2012. 
their broader institutional and policy contexts: asylum and refugee policy, Frontex and the EU's border security policy, and the promise and dangers of various models of disaggregated citizenship operating within the European legal space. I conclude with a preliminary discussion of the political task that we might appropriately call European cosmopolitics: the reinvention of emancipatory and utopian possibility into the future, beyond the nation-state to the droit de cité, the assertion of unconditional citizenship. Here, the European city - as a site in which the droit de cité can be anticipated and achieved - is where new supranational sovereignties might be born.

\section{Introduction}

In March 1994, Václav Havel addressed the European Parliament and proposed the drafting of 'A Charter of European Identity', which 'would clearly define the ideas on which it [the European Union] is founded, its meanings and the values it intends to embody'. ${ }^{1}$ Havel spoke openly about the need to reconcile the hyper-rationalised, legalistic 'machinery' of EU integration with the cultural, symbolic, and spiritual dimensions of that same undertaking. Havel noted that European institutions might be quite efficiently integrated but that this alone can hardly serve as inspiration for a new European demos. 'It [the Maastricht Treaty] addressed', Havel said, 'my reason, but not my heart'. ${ }^{2}$ The current juridified form of integration is devoid of deeper emotional resonance, of a sense of belonging in common, of togetherness. If the European project is to be successful, according to Havel's reading, Europeans will need to appreciate Europe as a fulfilment of democratic community, of a social solidarity that is expressed through inclusion and participation in civic life. It is a solidarity that relies not only upon reciprocal rights-claims under transnational human rights law but also upon an orientation to a shared world of meaning-creation, in which the ideals of democracy disclose themselves in everyday practice. Europe and its political identity rely, in short, on the democratisation of the struggles of those who remain on the margins.

Motivating this article is thus the continuing, yet difficult, hope for a Europe of democratic cosmopolitanism, for a Europe in which cosmopolitics works to continually question the very terms of lingering exclusion. In part, this is a problem of the nation-state itself. Contemporary na-

\footnotetext{
1 Václav Havel, Speech in the European Parliament, Strasbourg, 8 March $1994<\mathrm{http}$ // www.vaclavhavel.cz/index.php?sec=3\&id=1\&kat=1\&from=115\#> accessed 10 June 2012. 2 ibid.
} 
tions largely have lost the capacity to retain sovereignty over matters of national importance, be they nuclear proliferation, climate change, mass migration, multiculturalism, or the pace and cruelties of global capitalism. It is at once a problem of necessity, the structural demands on governance in a globalised world, and of contingency, the moral-political interchangeability of citizens from one nation to the next. Once states 'pool' their sovereignties into transnational legal orders to regulate and tame cross-national concerns, national democratic identities are placed under considerable strain. ${ }^{3}$ The symbolic relationship of the democratic citizen to the rules and values that order her life, perhaps even give meaning to it as a free endeavour, is increasingly confused. Moreover, if we continue to believe in an ideal of self-legislation and democratic authorship, the ever more complex array of transnational legal instruments and distant bureaucracies should give us pause. We might, for example, question whether such arrangements can respond to the civic expectations of free peoples. We might wonder where the European project will take us if it continues to skip hastily over the absent European demos. ${ }^{4}$

And, yet, the matter is not as plain as reasserting 'the people' on a European scale. Or, rather, it must not be if Europe's anticipation of democratic cosmopolitanism is to be preserved. That is, if Europe is to avoid repeating and recreating the attendant exclusions of national chauvinism merely on a grander stage, Europe must not become a new, powerful super-state, its boundaries redrawn and reinforced, leaving those who were marginalised at the national level still-marginalised at the supranational level. The critical task is therefore to democratise the European transnational legal edifice, a framework which has already been erected in our name, if not wholly by our will. Only through such a political act can a new European identity assert itself freely. This act - if it is to be

\footnotetext{
3 See generally Jürgen Habermas, 'The European Nation-State: On the Past and Future of Sovereignty and Citizenship' (1998) 10(2) Public Culture 397.

4 Habermas himself, in paraphrasing a question first posed by Walter Benjamin, asks the following: 'Is it possible that one day an emancipated human race could encounter itself within an expanded space of discursive will formation and yet be robbed of the light in which it is capable of interpreting its life as something good? . . . Without the influx of those semantic energies with which Benjamin's rescuing critique was concerned, the structures of practical discourse-finally well established-would necessarily become desolate'. Jürgen Habermas, 'Consciousness-Raising or Rescuing Critique?' in Gary Smith (ed), On Walter Benjamin: Critical Essays and Recollections (MIT Press 1988) 123 [emphasis added].

In applying this insight to the supranational political context and in particular to the welldeveloped supranational structures of the European Union, we can identify an analogous fear inscribed within the future realisation of a cosmopolitan order. It is not necessarily that European society will be unable to see its accomplishment as something good; it is rather that just at the moment when Europe succeeds in integrating itself, the very semantic and utopian energies that had previously driven and given meaning to that integration will have slipped away. Precisely when Europe has proclaimed its unification, it will have concealed or perhaps even lost the very idea of itself.
} 
intelligible as cosmopolitan and as European - must directly question the accepted practices of inclusion and exclusion that have hitherto marked the national experience. The formation of a new European political identity is not, therefore, a matter of transnational legal process. It obtains in neither an act of law nor a pronouncement of elites. Rather, a European demos is to be found in the concrete political struggles that bestride and betray the borders as they have been drawn, in the struggles that question the logic of the border's continuing existence.

In what follows, I would like to expand the familiar criticism of Europe's democratic legitimacy gap, its democratic deficit. I intend to use this critique as a lens through which to analyse the possibility of a supranational participatory identity within the European political and cultural space. It is my hope to begin to make sense of what we might mean when we speak of a shared European identity and in what particular political struggles this identity might inhere. What is the relationship between particularity and universality, between the part and the whole, in an expanding political community of diverse Others? How does this relate to the project of political integration and enlargement to which Europe is currently committed? How is the interrogation of political identity to proceed, with which vocabularies, and on what terms? In all, I wish to explore the importance of the symbolic form for the process of cultural contestation, for the negotiations of deeply seated identities, and for the relevance of the European project into the future.

First, I describe the contemporary juridification of European politics and the dangers it poses to the project of democratic cosmopolitanism. I argue that the formal legalism through which the European Court of Justice has established a European 'constitutional' order has failed to foster an attendant supranational civic identity among Europe's citizens. Europe's contemporary crisis of democratisation, in which executive-judicial organs steer and administer political integration, leaves European solidarity stillborn. While transnational law has admirably reduced reliance on ethnic identities, it nevertheless cannot ground a new European demos, as such. In short, it cannot replace altogether a participatory European democratic politics.

Second, I offer a critique of Jürgen Habermas's constitutional patriotism as a viable frame in which Europeans might navigate the competing demands of particularism and universalism. The concept of constitutional patriotism fails to account for political affect and instead implicitly assumes an orientation on the part of citizens to determine their communal lives according to liberal-democratic principles. In seeking to dissolve the paradox of constitutional democracy, Habermas deprives cosmopolitan practice of its participatory solidarity and its motivational core. I thus argue that the expression of European political identity in 
constitutional patriotic terms is a false start, an insufficient conceptual prism through which to analyse political identity-formation. If the European Union is to regain the semantic and conceptual resources required to forge a coherent political identity, it must look elsewhere. Rather, following Bonnie Honig, I distinguish a more primary and original paradox confronting the European Union: the paradox of politics, which posits the radical indeterminacy of the demos as the starting place for the creation of identity. 'The people' is a body always in need of self-recreation through politics deprived of any ultimate reliance on the principles of law. The response of European cosmopolitan identity should be precisely to occupy this space of indeterminacy, to see itself as an incomplete political subject always disruptive of received limits and boundaries.

Third, I develop in greater detail the processes of symbolic identityformation, namely the interplay of inclusion/exclusion that characterises modern political attachment. At the heart of political identity, there is a profound split. Drawing on Ernesto Laclau's work on hegemony, I argue that the logic of identity is both disrupted by and constituted through the existence of an Other beyond a drawn (national) boundary. What this analysis will elucidate is that the problem of EU constitutionalisation and political integration is the problem of borders or of the closed polis, in general. In this sense, EU citizenship, migration and asylum policies, insofar as they confront the question of boundaries directly, are central to understanding the future of any shared European cosmopolitan identity. The appropriate symbolic frame of European political identity is that of the heterogeneous itself.

Next, I argue that the operative European political subjects are now in a certain sense the refugees, the sans-papiers, the third-country nationals, and the citizens of other (recently admitted or accession) European states, each of whom serves to remind EU nationals of the foundational contingency of their particular, existing legal orders. Practically, I analyse European citizenship and immigration laws within their broader institutional and policy contexts: asylum and refugee policy, Frontex and the EU's border security policy, and the promise and dangers of various models of disaggregated citizenship operating within the European legal space. In other words, I take the process of European integration and enlargement to be one of continually coming to terms with the limits, instability, and iterability of both law and identity. The figure of the refugee, perpetually held in between, presents a productive Arendtian 'exemplary validity' against which European citizens can question and re-evaluate their always-contingent political attachments.

Finally, I conclude with a preliminary discussion of the political task that we might appropriately call European cosmopolitics. The European project inheres not only in formalised integration according to public law 
but also in the processes of democratisation that seek alternative institutional arrangements, that seek to refresh unremittingly the political landscape. In part, this task is grounded in a project of enlargement sensitive to the encounter with the non-integrated Other, a project that reinvents emancipatory and utopian possibility into the future, beyond the nation-state to the droit de cité, the assertion of unconditional citizenship. Here, the European city - as a site in which the droit de cité might be anticipated and achieved - is where new supranational sovereignties might be born. It is within this space that solidarity, constitutionalism, and radical democracy are negotiated in an uneasy and ever-shifting discursive-political encounter, an encounter that can properly be termed cosmopolitan.

\section{The politics of depoliticisation and the juridification of European identity}

Historically, the politics of the European Union has disavowed a strong conception of democratic agonism, instead seeking to neutralise conflict and to draw upon consensual threads of a 'thin' universalistic identity. The pillars of European integration have been economic prosperity, transnational legal regulation, and international security. ${ }^{5}$ In this respect, the core of European politics has been and continues to be colonised by the logics of economics and law. ${ }^{6}$ Because judicial decision-making has channelled and driven European integration, Europe's supranational political space has therefore been to a considerable degree depoliticised. The question of a freely constituted European people's selfidentification, let alone of its self-legislation, has fallen altogether from view. While it may seem trite, today, to observe that the European public sphere is weak and underdeveloped, ${ }^{7}$ it nevertheless remains the case

\footnotetext{
5 Here, the public law institutions of Europe have not been grounded in anything resembling polemos or hostis. See Carl Schmitt, The Concept of the Political (University of Chicago 1996) 46-7. While Schmitt's friend/enemy distinction ought not be embraced in its existential-ontological sense, it is helpful analytically in highlighting the deficiencies of the legalistic European model. For Schmitt, liberalism's focus on the moralistic and economic aspects of law marginalises the political concepts of conflict and confrontation with the enemy. In this light, the European legal space rests on fundamentally depoliticised and demilitarised concepts, having as its goal precisely to make politics safe, 'to annihilate the political as a domain of conquering power and repression'. ibid 71.

6 See Jiří Př́ibán̆, Legal Symbolism: On Law, Time and European Identity (Ashgate 2007) 117.

7 Debates over the European Union's 'democratic deficit', of course, have long flooded legal and political science journals. See, eg, Giandomenico Majone, 'Europe's "Democratic Deficit": The Question of Standards' (1998) 4 ELJ 5; F. Decker, 'Governance Beyond the Nation-State, Reflections on the Democratic Deficit of the European Union' (2002) 9 Journal of European Public Policy 256; A Føllesdal \& S Hix, 'Why There is a Democratic Deficit in the EU: A Response to Majone and Moravcsik' (2005) Eur. Governance Papers, No C-05-
} 
that Europe has yet either to find or to found the demos for which the European Union stands as a hollow placeholder.

There is a sense in which this development might not trouble us. We might conclude, for example, that the process of civic interpellation simply takes time and that the founding paradox of Europe will resolve itself just as Jean Monnet's neo-functional integration had imagined all those years ago: politics will, indeed, follow step by step the path of economics, and 'governance' will surely turn into 'government'. ${ }^{8}$ Or, rather, we might assert along constructivist lines that new models of constitutional dialogue and public contestation among a diverse set of elite political actors might inspire new forms of solidaristic attachment currently eluding European civic psychology. But there are reasons, precisely in these times of severe economic crisis and political unrest, to be less optimistic. There are reasons to question the power of legal-technocratic coordination to inspire the broader civic solidarity upon which a European demos must ultimately depend. ${ }^{9}$ There are reasons, in other words, to begin the search for an alternative path towards a European future.

Our problem appears in greatest relief when we consider the nature of the constitutionalised European legal order: namely, the extent to which Europe has adopted the functional equivalent of a constitution through the treaties that established and expanded the European Community. This movement towards integration has been guided, above all, by legal formalism - and has involved many of its corresponding flaws. While European institutions - both supranational and national - have disseminated harmonised legal norms, their systems-coordination logic has accordingly neglected the symbolic dimension of democratic political identity. Put simply, Europe has inaugurated a new constitutional structure while leaving democracy behind, and it is now increasingly doubtful that a supranational European identity can continue to be articulated

02 <http://www.connex- network.org/eurogov/pdf/egp-connex-C-05-02.pdf> accessed 10 June 2012; Andrew Moravcsik, 'In Defense of the "Democratic Deficit": Reassessing Legitimacy in the European Union' (2002) 40 Journal of Common Market Studies 603; Andrew Moravcsik, 'The Myth of Europe's "Democratic Deficit"' (2008) Intereconomics: Journal of European Economic Policy 331.

8 See, eg, Andrew Moravcsik, 'Preferences and Power in the European Community: A Liberal Intergovernmentalist Approach' in S Bulmer \& A Scott (eds), Economic and Political Integration: Internal Dynamics and Global Context (Blackwell Publishing 1994) 29-80. This approach is currently on view in the latest intergovernmental agreements on a closer European fiscal union, pushed through in a time of great economic emergency with constrained public debate.

9 Some theories might wish to sidestep the demos altogether, but I believe that the question of a redefined European democratic polity remains indispensible to imagining a fully free European citizenry. Without the coherence of a European demos as a referential ideal, possibilities for democratic civic action would be significantly foreclosed. 
through legality alone. Indeed, today Europe appears to be at a paradoxical and uncertain moment in its development. ${ }^{10}$

At issue here is the very legitimacy of the European project. While modern political legitimacy certainly inheres partially in legal form and in the provision of rights under the rule of law, legitimacy also requires its democratic dimension: the participation of the people in a political project they can intelligibly call their own. ${ }^{11}$ The processes of European integration have harnessed the former while essentially dispensing with the latter.

Legally and institutionally, it must be said that the European cosmopolitan achievement is considerable: the arrangement of a discrete European system of government and the interpenetration of national and European laws in a trans-European 'constitutional' system of rights protection and judicial review. ${ }^{12}$ In large part, the European Union's authority no longer relies strictly on the mediation of national political structures, though often the latter serve to accredit superficially the decisions of the former. European law occupies an effectively autonomous sphere, with its own endogenous conditions for legality and validity. The jurisdiction of the European Court of Justice and the preliminary reference procedure under Article 234 TEC/Article 267 TFEU successfully pierced national court systems and activated national judges as agents of the European legal order. ${ }^{13}$ Through its jurisprudential doctrine of su-

10 As Hauke Brunkhorst has observed, 'The already quite advanced status of European constitution making is simultaneously increasing both the chance for a transition from a weak to a very strong European public sphere, and the danger of constitutionally solidifying the de-democratization of Europe and its nations'. Hauke Brunkhorst, Solidarity: From Civic Friendship to a Global Legal Community (MIT Press 2005) 163-4. The longevity of the fiscal union and its impact on political integration-noting the dissenting voices of the United Kingdom and the Czech Republic, as well as the deepening economic crisis in Greece-remain to be seen.

11 This distinction is often made in terms of 'output-legitimation' and 'input-legitimation'. See ibid 139-40.

12 See JHH Weiler, 'The Transformation of Europe' (1991) 100 Yale Law Journal 2403. In 1986, for example, the European Court of Justice noted 'that the European Economic Community is a Community based on the rule of law, inasmuch as neither its Member States nor its institutions can avoid a review of the question whether the measure adopted by them are in conformity with the basic constitutional charter, the Treaty." Case 294/83 Parti Ecologiste 'Les Verts' $v$ Parliament [1986] ECR 1339, para 23. Moreover, the European Court of Human Rights has itself called the European Convention 'a constitutional document' of European public law. Loizidou v Turkey App no 15318/89 (ECHR 23 March 1995).

13 Treaty on Functioning of the European Union, Consolidated Version, 30 March 2010, art 267 [2010] OJ C83/47. 
premacy $^{14}$ and the direct ${ }^{15}$ and indirect ${ }^{16}$ effect of European law in various policy areas, the European Court of Justice over time has fashioned the hierarchical constitutionalisation of the European treaty system.

Nevertheless, EU judicialisation has failed to inspire an attendant political-psychological transformation in the consciousness of newly minted European citizens. This failure is attributable in no small part to the fact that, precisely on the symbolic level of political identity, European functional constitutionalism offers a severely anaemic alternative to national constitutional law. European law engages Europeans not as authors of the law of which they are ultimately subjects but rather as the juridified objects of a new, if increasingly harmonised, regulatory apparatus. Hauke Brunkhorst cites the following deficiencies in the EU legal framework: 'discrimination of residents, potential deportation of EU citizens out of individual countries, democratically insufficient rights to participation, privileging of the executive and the state apparatus'. ${ }^{17}$ While it is true that the European treaty system has been steadily evolving and can be changed, the degree to which individual citizens influence this change is constrained and heavily mediated by bureaucracy, legal-expert regulation, and other elite, non-democratic organs. European Union law responds to the need for further integration in systems-structural terms, not necessarily in terms of the communal self-identification that normally accompanies democratic constitutional development. ${ }^{18}$

In the EU, elite executive organs of treaty-ratifying countries alongside transnational legal processes - and not European citizens or their direct representatives - are the authors of constitutional change in any proximate and meaningful sense. ${ }^{19}$ Moreover, the customary parliamen-

\footnotetext{
14 Supremacy operates here in the sense that Community law cannot be overridden by domestic statute, contrary to the general principle of lex posteriori. Case 6/64 Flaminio Costa $v$ ENEL [1964] ECR 585. Later, the ECJ confirmed further that Community law cannot be overridden even by the basic constitutional law of a European Member State. Case 11/70 Internationale Handelsgesellschaft $\mathrm{mbH} v$ Einfuhr- und Vorratstelle für Getreide und Futtermittel [1970] ECR 1125. See also Case 106/77 Amministrazione delle Finanze dello Stato $v$ Simmenthal SpA [1978] ECR 629.

15 See Case 26/62 NV Algemene Transporten Expeditie Onderneming van Gend en Loos $v$ Nederlandse Administratie der Belastingen [1963] ECR 1.

16 See Case 106/89 Marleasing SA v Comercial Internacional de Alimentacion SA [1990] ECR I-7321.

17 Brunkhorst (n 10) 165.

18 To put it plainly, [the European constitutional framework] is less protected against non-egalitarian and manipulative interventions and encroachments than typical national constitutions'. ibid 165. See also Weiler (n 12) 2405-6; and JHH Weiler, 'The Reformation of European Constitutionalism' (1997) 1 Journal of Common Market Studies 97-8.
}

19 Alec Stone Sweet has recently written about the emergent 'cosmopolitan legal order' within the European Union. In particular, the rights-oriented jurisprudence of the European Court of Human Rights and the adoption of Protocol No 11 (conferring compulsory 
tary mechanisms of European Member States are themselves increasingly marginalised in political decision-making at the supranational level. While there have been significant referenda and an increased interest in the European Parliament, real authority and control still lie with the European executive organs and, more subtly, with the latent legal evolution of transnational economic regulation, or the new lex mercatoria. ${ }^{20}$ Further, the ability to initiate legislation continues to rest with the nondemocratic European Commission, as national or European parliamentary competency is limited largely to the comparatively weak powers of veto, consultation, supervision, and amendment. ${ }^{21}$ The modern political sources of solidarity, emerging from democratic processes of self-legislation and normative self-identification, are thus in the European Union invariably confused, diluted, and undermined. ${ }^{22}$

Today, this same crisis in the democratisation of European power is visible in the intergovernmental terms of the emerging fiscal compact. Under the Treaty on Stability, Coordination and Governance, European heads of state of the European Council would be granted far-reaching powers to annul budgetary policies of national parliaments. ${ }^{23}$ The

jurisdiction over individual petitions) have ensured the domestic incorporation of transnational European norms. Alec Stone Sweet, 'A Europe of Courts: Constitutional Pluralism and Rights Cosmopolitanism' (2011) Law and Globalization Seminar, Spring 2011, Yale Law School, draft. I consider the rights protections afforded by the ECHR and its dialogic relationship with domestic courts to be no doubt a welcome development that ought be praised and valued. Nevertheless, in the context of post-national identity formation, I also take it to be an incomplete development: in connecting individuals to a supranational court, it remains too embedded in the legalism I have been discussing above. For this kind of rights cosmopolitanism to penetrate the symbolic political universe, it is in need of extra-legal supplement, an additional channel for the expressions of solidarity. See also Alec Stone Sweet, The Judicial Construction of Europe (OUP 2004).

20 See, eg, Alec Stone Sweet, 'The New Lex Mercatoria and Transnational Governance' (2006) 13 Journal of European Public Policy 627.

21 See Weiler, 'Reformation of European Constitutionalism' (n 18) 113.

22 As Brunkhorst puts it: 'Although citizens were long ago recognized as subjects of integration in status activus, the status activus of the people of the Union has been up to now only nominal-symbolic constitutional law: legal text, but no concretized legal norm'. Brunkhorst (n10) 172. The marginalisation of democratic legitimacy is perhaps reaching its crisis point. Today, in the face of the sovereign debt crisis, democracy in certain states has been effectively suspended, virtually forgotten as an important factor in addressing national and European problems. Both Italy and Greece have recently acquired apolitical technocrats as interim heads of government (Italy's entire Cabinet is comprised of technical experts), and parliamentary democracy has been progressively marginalised to the point where it is regularly overruled by executive emergency decision. While administrative governments have calmed the nerves of the European Central Bank and the international financial markets, they have unwittingly exacerbated the very crisis of legitimation that plagued the European Union to begin with. See generally Jürgen Habermas, On Europe's Constitution-An Essay (Suhrkamp 2011).

23 See Treaty on Stability, Coordination and Governance in the Economic and Monetary Union (Fiscal Treaty) 2 March 2012, arts 5 and 6. 
Treaty, though explicitly requiring profound changes to be incorporated into Eurozone members' constitutions, ${ }^{24}$ is carefully constructed to avoid referenda. ${ }^{25}$ Jürgen Habermas has recently written on the potential undemocratic consequences of the emergency measures, a reckoning with 'a post-democratic empowerment of the executive on an unprecedented scale'. ${ }^{26}$ Habermas notes that "the "economic dialogue" foreseen by the permissive clause in paragraph $2 \mathrm{~h}$ [Article 11c] of the . . resolution of the European Parliament of 28 September 2011 is not sufficient to close this [democratic legitimacy] gap'. ${ }^{27}$

Thus, at stake in recent moves toward European integration is the critical distinction between (a) having secure access to an array of modern rights and (b) achieving that access intelligibly as democratic subjects. What might objectively be an inspiring and progressive realisation of human rights remains subjectively (that is, for individual citizens themselves) a hierarchically structured deliverance from above, from a technocratic legal apparatus that - though benevolent - is unmistakably distant. It remains, with only some exaggeration, almost foreign, which is to say, removed from immediate procedures of democratic legitimation and political self-identification. Thus, even the sophisticated process of European constitutionalisation cannot replace entirely the symbolic activity of European identity-formation and its associated civic imaginary. As Ian Ward argues, legalism alone is insufficient to ground what he calls a new European public philosophy:

24 Para 15 of the Preamble to the Fiscal Treaty reads: "NOTING that compliance with the obligation to transpose the "Balanced Budget Rule" into national legal systems through binding and permanent provisions, preferably constitutional, should be subject to the jurisdiction of the Court of Justice of the European Union...' (emphasis supplied). Art 3 para 3 further stipulates that ' $[t]$ he rules shall take effect in the national law of the Contracting Parties... through provisions of binding force and permanent character, preferably constitutional, or otherwise guaranteed to be fully respected and adhered to throughout the national budgetary processes' (emphasis added). Germany, the driving force behind the Fiscal Treaty, amended its Constitution in 2009 to require that a balanced budget (Schuldenbremse or 'debt brake') on both the federal and the state levels be gradually introduced, with 2020 as the final date after which no deficit would be permitted. In November 2011, the Austrian government agreed to a similar amendment, while comparable provisions had already been adopted in the 1990s by Switzerland, Estonia, and Poland.

25 In a surprising move, the Irish government decided to call a referendum. Valentina Pop, 'Ireland to Hold Referendum on Fiscal Compact' EUObserver (28 February 2012) <http: // euobserver.com/18/115412> accessed 10 June 2012. The Fiscal Treaty nonetheless has a safety valve that protects it from being blocked by a minority of Member States. It is formally excluded from the EU constitutional framework, thereby allowing the Member States to circumvent the traditional amendment provision of the TEU, that is, ratification by all 27 Member States. The new Treaty will take effect after ratification by 12 states.

26 Jürgen Habermas, 'Bringing the Integration of Citizens into Line with the Integration of States' (12 March 2012) ResetDOC (Ciaran Cronin, tr) <http://www.resetdoc.org/story/00000021925> accessed 10 June 2012.

27 ibid. 
A public philosophy is a state of mind, something refined by the political imagination. It is, ultimately, a matter of belief. If Europe has a future, it must be something that Europeans believe in, not something the legitimacy of which is assigned merely by treaties and courts of law. ${ }^{28}$

Or, as Joseph Weiler writes rather bluntly: 'The ability to go to court to enjoy a right bestowed on you by the pleasure of others does not emancipate you, does not make you a citizen'. ${ }^{29}$ While a transnational cosmopolitan law might serve to reduce reliance on ethnic identity as a holistic category, ${ }^{30}$ it nevertheless cannot at the same time inspire attachment to a new European demos, as such. In short, it cannot substitute for a participatory European democratic politics, through which new political subjects and a new political solidarity can emerge.

When we speak of the political imagination or of democratic emancipation, we therefore arrive at the intrinsic limits of transnational constitutional law. Missing is the moment of will, ${ }^{31}$ in which Europeans could demand that the text of this constitutional shell be presented to the people directly for a world-creating moment of constitution. ${ }^{32}$ In other words, for the European public space to be realised coherently, European constitutionalisation must be a process attained and claimed by the demos for

\footnotetext{
28 Ian Ward, 'Beyond Constitutionalism: The Search for a European Political Imagination' (2001) 7 European Law Journal 24, 25.

29 JHH Weiler, 'To Be a European Citizen-Eros and Civilization' (1997) 4 Journal of European Public Policy 503; see also Weiler, 'Reformation of European Constitutionalism' (n 18) 114-5.

30 I should stress here that this value should rightfully be celebrated as a significant achievement of the European project. Nevertheless, as I discuss later, in order for this cosmopolitan accomplishment to endure and to continue to guide our political consciousness into the future, it must confront the question of its own political legitimacy. In the absence of such legitimacy, cosmopolitan virtue will be unable to compete practically and symbolically with the nationalist responses that are already appearing today. Indeed, because we have, in the end, depoliticised our politics, the logics of xenophobia, chauvinism, and anti-immigrant racism have taken hold in even the traditionally most progressive of states (see the recent French and Dutch moves to ban wearing the burqa in public). See below section 4 .

${ }^{31}$ See Paul W Kahn, Putting Liberalism in Its Place (Princeton UP 2004); Paul W Kahn, Out of Eden: Adam and Eve and the Problem of Evil (Princeton UP 2006); Paul W Kahn, Political Theology: Four New Chapters on the Concept of Sovereignty (Columbia UP 2011).

32 See Brunkhorst (n 10) 174. I want to stress that the issue encountered here does not concern, in particular, the incomplete formation of a State, as such (namely a European super-state). The process of constitutionalisation does not logically assume the creation of a unified State but leaves contingent various institutional configurations that might retain core competencies within federated and diverse jurisdictions. Indeed, it would diminish the noble ambitions of the European Union simply to recreate the 'nation'-state, with all of its failings, at the European level. See below, sections 3 and 4 . The point here, rather, is that, in order for any European project on the supranational level to proceed with the confidence and trust of European citizens, constitutionalisation must find points of reference in participatory, democratic processes of self-identification.
} 
itself. The constituent power cannot be brought into being retroactively. The demos cannot be freely formed through laws of which it is not at the same time the author. Democratic identity - and its attendant civic virtues of trust and solidarity - simply cannot be bootstrapped in this way.

The legalistic nature of Europe's founding thus lingers as a paradox of identity that presents longer-term, structural challenges for European enlargement and integration. What might the concept of a new European public philosophy concretely mean, and in what structures might it be expressed? From where might a European political identity emerge? How might it be put into practice and lived by European citizens?

The proclamations of EU law provide little help here. Article 49 of the Treaty of the European Union states that '[a]ny European State which respects the values referred to in Article 2 and is committed to promoting them may apply to become a member of the Union'. ${ }^{33}$ Article 2 enumerates the 'values of respect for human dignity, freedom, democracy, equality, the rule of law and respect for human rights, including the rights of persons belonging to minorities' and indicates that they are 'common to the Member States in a society in which pluralism, non-discrimination, tolerance, justice, solidarity and equality between women and men prevail'. ${ }^{34}$ Nevertheless, the contours of a specifically European identity - apart from a vacuously thin declaration of liberal democratic principles - are entirely underdetermined. Furthermore, Article 4.2 emphasises that the Union 'shall respect [Member States'] national identities, inherent in their fundamental structures, political and constitutional, inclusive of regional and local self-government'. ${ }^{35}$ And yet, once again, the relationship between a new European political consciousness and familiar national identities is rendered very much unclear. Further, if left unresolved politically, this ambiguity will very likely be corrosive of the future relevance and legitimacy of the European project, especially with regard to the 'additional' European citizenship granted at Maastricht. ${ }^{36}$ As Étienne Balibar writes:

[I]t is difficult to conceive of supranational institutions being recognized as legitimate if they do not procure for the individuals they bring together an at least equal (and in fact greater) level of security and degree of democratic participation than existed in the framework of traditional nation-states. ${ }^{37}$

\footnotetext{
33 Treaty on European Union, Consolidated Version, 30 March 2010, art 49 [2010] OJ C83/01 (hereinafter Consolidated TEU).

34 ibid, art 2.

35 ibid, art 4.2.

36 See ibid, art 9.

37 Étienne Balibar, We, the People of Europe? (Princeton UP 2004) 43.
} 
This legitimation gap is exacerbated in times of economic crisis and, despite recent elite moves to push forward ever-closer political union at the institutional level, this deficit exposes the European project to the perils of populist and xenophobic eruptions. These eruptions are echoed in Europe's strict policing of its external boundaries and its increasingly hostile immigration policies. There is every reason to fear that, if Europe cannot find a way to re-democratise and re-legitimate itself and its constitutional framework, the regression to older forms of chauvinism could be serious, indeed.

If the question of the demos as such is to be framed properly, the issue of political identity must be addressed directly (and certainly must not be limited to the formal discourse of public law). Indeed, this core political question ought to be a locus of prolonged public contestation, through which provisional and plural self-understandings might slowly emerge: Why ought a unified Europe exist at all? For what purpose ought its citizens work together as participants in a common political project? ${ }^{38}$ In order to better understand the limits of European constitutionalism and the promise of a European democratic cosmopolitanism, I now turn in greater detail to the interplay of law and politics, of governance and democratic freedom, of constitutional principle and public trust.

\section{From constitutional patriotism to the perpetual paradox of politics}

The construction of a distinctly transnational European legal landscape over the past decades confronts us as European citizens with a conspicuous problem: how do we, as democratic subjects, find autonomy and freedom in relation to a framework of laws not strictly or intelligibly of our creation? In a certain sense, the European dilemma is at heart a dilemma of constitutional democracy itself, faced by all peoples who decide to found

\footnotetext{
38 See generally Jürgen Habermas, The Postnational Constellation: Political Essays (Polity Press 2001) 60-1. In this sense, it is a great hope that-should the new Treaty on Stability, Coordination and Governance inspire a broader public debate about European economic and social policy - this debate would reflect upon the question of political identity and interrogate the European project conceived not as super-state but as 'post-national constellation'. The fear, of course, is that such a debate will instead rather quickly lapse into technocratic legalism and economic determinism with few opportunities for more widespread civic participation. This is the democratic tragedy behind the Greek bailouts. Even taking account of the severe economic concerns, Papandreou's initial appeal for a referendum on an issue of fateful importance to Greek citizens was met with vitriol from European political elites and bankers. The dividing line between democratic political accountability and economic necessity had never been greater. The crisis confronted citizens with a corrosive false choice: either be bad democrats or be bad Europeans. See, eg, Costas Lapavitsas, 'Greece Crisis: Papandreou's Referendum is a Gamble Too Far' The Guardian (1 November 2011) <http://www.guardian.co.uk/commentisfree/2011/nov/01/greece-crisispapandreou-referendum-gamble> accessed 10 June 2012.
} 
their democratic life with reference to a binding constitutional text. Our civic alienation from European law is therefore in part a problem common to all forms of constitutional law. The laws that bind us belong always already to the past; they are not necessarily 'of our time,' despite their continual translation. The past legislates over the present, the present over the future. ${ }^{39}$ Here, the constitution is distinct from the people at any one point, and the rule of law stands above the simple (majoritarian) self-rule of men.

And, yet, we as Europeans are alienated from EU law doubly: not only by time but also by what we might perceive to be a spatial-hierarchical divide. This divide, perhaps even more than the temporal disjunction, is exacerbated by the democratic deficit described above, in which the EU functional constitutionalisation lacks its proper constituent power or founding moment. This second alienation from Europe concerns the struggle between the supranational intergovernmental project, on the one hand, and particular national attachments and histories, on the other. More broadly, in the language of human rights protection, it is the struggle between universality and particularity, between universal moral principles and particular cultural-political ethics. We frequently speak about this dilemma with metaphors of spatial distance and ordering: a 'universal' Europe that spans or crosses the boundaries of individual nation-states. Brussels is presented as all but a 'foreign country', and universality is cast as a questionable intrusion of international law into the particular value spheres of a national polity.

The discords of past and present thus overlap with the tensions of the universal and the particular, and today's European citizens engage in a situated democracy continuously confronted by a constitutional past and an abstract, distant universalism. The European Union, therefore, is perpetually 'out of joint' with our democratic selfhood.

In response, Jürgen Habermas has proposed a theory of constitutionalism that would dissolve this dilemma and thereby ease the alienation of European citizens from the structures of European law. ${ }^{40}$ Haber-

\footnotetext{
39 Some thinkers have argued that this structure means that constitutional democracy must therefore be considered an intergenerational project that actualises freedom and autonomy only through time. See, eg, Stephen Holmes, 'Precommitment and the Paradox of Democracy' in Jon Elster (ed), Constitutionalism and Democracy (CUP 1988); Jed Rubenfeld, Freedom and Time: A Theory of Constitutional Self-Government (Yale UP 2001). In this sense, the dilemma is in effect no dilemma at all, as the discomfort of illegitimacy dissipates amidst talk of heirs and beneficiaries united through quasi-mythical national experience. This mythology is, of course, precisely what Europe in the end lacks, and this lack is related to the second (spatial) line of alienation. As we shall see, Habermas attempts a similar conceptual move with his discourse theory of law, where freedom is ultimately harnessed in constitution-making through time.

40 See generally Jürgen Habermas, 'Citizenship and National Identity: Some Reflections on the Future of Europe' (1992) 12(1) Praxis Intl 1; Jürgen Habermas, 'Why Europe Needs
} 
mas rejects the antagonism of law and democracy and argues that they are instead mutually constitutive, dependent on one another for their full realisation. For Habermas, therefore, constitutional democracy at the European level promises to overcome the divisions of particular national interests without undermining civic democratic life itself. As I will argue, however, Habermas's approach is ultimately insufficient either to ease or to remove the gap in European democratic legitimation.

Habermas advises that the European nation-state's internal relationship between republicanism and nationalism be reconsidered. While it may admittedly be impossible to remove wholly the pre-political basis of collective identity from legal process, pre-political identities might nevertheless be progressively reformulated by the discursive procedures of constitution-making. Indeed, as the growing diversity of cultural forms of life and worldviews renders homogeneity impossible as a form of national grounding, the impulses of republicanism must be strengthened and re-emphasised. 'The central idea of republicanism', Habermas writes, 'is that the democratic process can serve . . . as a guarantor for the social integration of an increasingly differentiated society'. ${ }^{41}$ In this sense, the common political culture of a state is gradually decoupled from pre-political identities or sub-political cultural foundations. Habermas proposes that the constitution be the formal means by which a "national culture develops a distinctive interpretation of those constitutional principles that are equally embodied in other republican constitutions - such as popular sovereignty and human rights - in light of its own national history. ${ }^{42}$

As such, the constitutional legal order and its accompanying constitutional patriotism - the affective attachment to the system of rights protection - might effectively displace nationalist recognition and its harmful particularist tendencies. In its stead, constitutional patriotism would champion a procedural basis for social cohesion and identity-formation within a post-metaphysical, pluralistic polity. Habermas thereby, in part, acknowledges the dual nature of universalism, which is both destabilised by yet also dependent upon its instantiation within 'binding' particular identities. ${ }^{43} \mathrm{He}$ has observed, 'On the basis of universalistic norms, no particular entity possessing an identity-forming power [such as the family, tribe, or nation] can set up bounds to demarcate itself from

a Constitution' (2001) 11 New Left Rev 5; and Jürgen Habermas, 'Toward a Cosmopolitan Europe' (2003) 14(4) Journal of Democracy 86.

41 Habermas, 'European Nation-State' (n 3) 408.

42 ibid.

43 See, eg, Patchen Markell, 'Making Affect Safe for Democracy? On "Constitutional Patriotism"' (2000) 28(1) Political Theory 38, 41. 
alien groups'. ${ }^{44}$ Nevertheless, Habermas's response is to insist that 'basic norms of rational discourse' can themselves ground a collective identity through which universal principles will assume a social reality and be interpreted practically through particular cultural lenses. ${ }^{45}$ In the end, a post-metaphysical, procedurally guided collectivity would self-identify with the common 'consciousness of [a] universal and equal opportunity to participate in value and norm-forming learning processes'. ${ }^{46}$

For Habermas, constitutional patriotism is a mode of civic belonging that has shed its dependence on a pre-political referent and instead has found a legitimating core in precisely its self-conception as a 'self-determining political community'. ${ }^{47}$ The hope of constitutional patriotism, in short, is to retain the affective identification of democratic politics while tethering that affect to rationally grounded moral and political principles. In so doing, constitutional patriotism offers a political framework that would actively valorise democratic interpretations of universal norms without necessarily marginalising minority groups as a community's Other. Indeed, the process of contestation would serve, under constitutional principles, to integrate individuals into a discursive community through which identities could be reconstructed reflexively.

Nonetheless, it remains contested whether constitutional patriotism per Habermas's formulation can provide an adequate response to the demands being made on the European nation-state both by economic integration and by multiculturalism. In particular, in its attempt to reconcile the narratives of technocratic and economic globalisation with the relations of social solidarity, constitutional patriotism expounds a rather limited view of political culture and of its role in nurturing the very identities required by democratic politics. ${ }^{48}$ On Habermas's reading of the development of modernity and the emergence of a post-metaphysical age, the public justification of communal norms nevertheless still refers to a disembodied 'ideal speech situation' expressed in abstractly aligned constitutional procedures and human rights. While Seyla Benhabib has

\footnotetext{
44 Jürgen Habermas, 'On Social Identity' (1974) 19 Telos 94.

45 ibid 100.

46 ibid.

47 Jürgen Habermas, Between Facts and Norms: Contributions to a Discourse Theory of Law and Democracy (William Rehg tr, MIT Press 1998) [1992] 496. In a sense, constitutional patriotism is Habermas's attempt to make progress on the problem of collective identity distinct to modernity. Indeed, it might be seen as an attempt to generalise the civic nationalism that had successfully emerged within a select group of nation-states in Western Europe and within the United States.

48 Patchen Markell has criticised Habermas's constitutional patriotism precisely as an example of a 'strategy of redirection', which 'rests on a misleading picture of the dynamics of political affect and, in particular, of the relationship between affect and the universal principles that supposedly are represented by the civic [order]’..Markell (n 43) 39.
} 
since reformulated this interaction of the universal with particular political-cultural communities in her concept of 'democratic iterations', ${ }^{49}$ we might stress that a modern constitutional process must resonate not only with a system of abstract rights but also with a deeper social imaginary that itself shapes communal life and political possibility.$^{50}$ It is this latter social imaginary that, though it is crucial to the success of any project of constitutional patriotism, is less well developed in the Habermasian model.

Along these lines, Craig Calhoun helpfully distinguishes between the notions of constitution as legal framework and constitution as the creation of concrete social relationships, each of which is necessary for a fully developed constitutional-democratic system. ${ }^{51}$ On this account, the mutual commitments made by individuals within a constitutionally instituted and legally structured public sphere depend not only on the law but also on solidarity, on a reciprocally embraced orientation to fellow citizens and to the political process. ${ }^{52}$ Calhoun stresses 'the role of public life in actually constituting social solidarity and creating culture' and includes within the processes of public deliberation 'modes of cultural creativity and communication not the less valuable for being incompletely rational. ${ }^{53}$ This richer form of democratic political culture signifies, in part, the indirect effect of politics on a society's system of cultural reproduction and collective self-identification. In this sense, the demos transcends the political or constitutional context and, more exactly, 'serves as the source of identity, morals, emotions, and collective behaviors . . . [shaping] a socially specific habitus' ${ }^{54}$ A true political culture enables a strong sense of shared responsibility and a duty of civic participation. ${ }^{55}$ In the end, Calhoun's intervention aims to make Habermas's constitu-

\footnotetext{
49 See, eg, Seyla Benhabib, The Rights of Others: Aliens, Citizens and Residents (CUP 2004); Seyla Benhabib, Another Cosmopolitanism (Robert Post ed, OUP 2005); Seyla Benhabib, 'Democratic Exclusions and Democratic Iterations: Dilemmas of "Just Membership" and Prospects of Cosmopolitan Federalism' (2007) 6 European Journal of Political Theory 44562.

50 In this sense, we might recall Hannah Arendt's analysis of revolution as a founding par excellence, as a rupture through which public action opens upon a new world and, indeed, shapes a new future. See Hannah Arendt, On Revolution (Penguin 1977).

51 Craig Calhoun, 'Imagining Solidarity: Cosmopolitanism, Constitutional Patriotism, and the Public Sphere' (2002) 14(1) Public Culture 152-3.

52 Calhoun points to the Hegelian dialectic of the whole and its parts as part of the very essence of modernity's relation between the individual and the nation, as they are 'complicit with each other' and 'continue to inform each other'. ibid 154.

53 ibid 155.

54 Dominique Schnapper, Community of Citizens: On the Modern Idea of Nationality (Transaction Pub 1998) 85.

55 See Jeremy Waldron, 'Cultural Identity and Civic Responsibility' in W Kymlicka \& W Norman (eds), Citizenship in Diverse Societies (OUP 2000) 155-74, 155.
} 
tional patriotism responsive not only to universal principles of inclusion and procedural coherence but also to the demands of social solidarity and to the questions of motivation and trust.

In this vein, while I share Habermas's hope for a reflexive reconstruction of political identity, I believe that Habermas's constitutional patriotism suffers from several shortcomings. Perhaps most important is the problem of motivation: the extent to which citizens are able to retain genuinely and deeply held attachments to abstract constitutional principles is uncertain - no matter how sensitively such abstractions might be interpreted alongside particular cultural histories. Even were this to be affirmed, the question remains why individual citizens would be motivated in the first place to participate in the processes of democratic iteration. ${ }^{56}$ Put simply, absent from our account of constitutional patriotism is a fuller articulation of post-nationalist participatory-political identity, an identity that would recognise and support legitimate democratic opinion- and will-formation.

Seyla Benhabib has argued that jurisgenerative politics are always negotiated in a dialectic of universalistic norms and particular contents dictated by the 'horizons' of identity, culture, and institutions. ${ }^{57}$ Habermas himself writes that the norm-justification inherent to constitutional patriotism requires a 'mature capacity for moral judgment' which integrates both 'cognitive operations and emotional dispositions and attitudes' in the participants' performative frame. ${ }^{58}$ Thus, rational justification and subjective affect must operate jointly. However, this inter-connection remains frayed or, at the very least, underdeveloped. Because the willingness to engage in such responsible negotiation seems to be dependent on some form of the above political identity, the concept of constitutional patriotism thus conceived may remain (viciously) circular: our cohesive identities emerge as shaped by political processes, but to participate fully in those processes requires the very identities these same processes are supposed to constitute. In other words, a demos capable of embracing liberal-democratic principles requires a desire on the part of

\footnotetext{
56 Sharon Krause has interpreted this 'motivational deficit' in terms of the division in Habermas's work between the moral and the ethical and has questioned whether this strict distinction, if the discourse ethical project is to be successful, can remain. She worries, in the end, the demands of universal proceduralism - and the infusion of reflexivity into what was previously an ethical domain with its particular form of the good-might result in a 'loss of confidence in reason and the end of rational discourse as a normative ideal'. Sharon Krause, 'Desiring Justice: Motivation and Justification in Rawls and Habermas' (2005) 4(4) Contemporary Political Theory 374.

57 See Seyla Benhabib, 'Claiming Rights Across Borders: International Human Rights and Democratic Sovereignty' (2009) 103(4) American Political Science Review 691-704.

58 Jürgen Habermas, Moral Consciousness and Communicative Action (C Lenhardt and SW Nicholsen trs, MIT Press 1996) 182.
} 
that community to determine legitimately the course of its communal life - that is to say, requires a desire for the very liberal-democratic principles we need to explain.

Here, patriotic attachment to liberal-democratic principles obliges an aspiration to a particular kind of self-determining politics, a legitimate kind in which discourse is open to all affected. Missing again seems to be an account of the origins of participatory-political solidarity - of the kind adequate to inspire sacrifice and even love for our neighbours, for the state as a whole, for strangers within our expanding symbolic universe - that can animate universalising inclusion, in the first place, while remaining relevant to particular ethical constructs. Without such an articulation, the project of cosmopolitan patriotism is in danger of shortcircuiting, failing to ever truly develop in a way recognisable to itself and to its intended normative commitments.

Moreover, amidst this deficit of solidarity within constitutional patriotism returns the spectre of the political. As cosmopolitan or supranational projects develop - even as outgrowths of the process of globalisation - political reactions invoking more insular and less inclusive versions of social solidarity materialise in response. If constitutional patriotism is to provide a fruitful model for the continued expansion of European cosmopolitan ideals into the realm of practice, its resilience in the face of the political question - and with it the problems of motivation and of solidarity - becomes increasingly salient. Indeed, Habermas himself has recognised the possible limitations of his approach and has posed the critical question in this way: 'Under what conditions can a liberal political culture provide a sufficient cushion to prevent a nation of citizens, which can no longer rely on ethnic associations, from dissolving into fragments?'59 In fact, Habermas supplements the conceptual co-originality of constitutionalism and democracy with reference to empirical events, namely the constitutional assemblies of Philadelphia and Paris. ${ }^{60}$ Thus, we already have - even within the context-transcending procedures of constitutionalism - an appeal to the exogenous traces of political affect, to the particular emotions of the founding moment of democratic politics. ${ }^{61}$

59 Habermas, 'European Nation-State' (n 3) 408.

60 See Jürgen Habermas, 'Constitutional Democracy: A Paradoxical Union of Contradictory Principles?' (2001) 29 Political Theory 766, 768.

${ }_{61}$ In the following sections, I work to outline what such traces of political affect and political subjectivity might be in the context of the construction of European supranational identity. 
Étienne Balibar summarises this point nicely:

[W] hat cannot work here is a unitary or federal formal constitution considered to be a 'fundamental law' (Grundgesetz) or a catalog of democratic rules and principles that would have to be intellectually 'recognized' by states . . . Such a definition presumes to be resolved what is in fact in question: the nature and existence of the constituent power on the European level. ${ }^{62}$

For Balibar, a constitution is not merely a form of juridical right. It is, rather, a dynamic of social and political practices that, while never bypassing the formal juridical moment, spreads out immediately beyond it, both in anticipation and application. If our task is to explain how a European demos might emerge, we cannot take the existence of a robust European political identity for granted. If the demos is elusive, so too is the supposed foundation of constitutional patriotism. Thus, if the European Union is to restore the conceptual and motivational resources required to refashion a supranational political identity, it must look elsewhere.

Following Bonnie Honig, I believe the dilemma of constitutional democracy, to which Habermas proposes constitutional patriotism as a resolution, is ultimately imbricated in a more basic and (for our purposes) more illuminating paradox. Indeed, it is this paradox that confronts directly the motivation deficit and the question of affective politics identified above. What is needed is a change in frame, a parallax view onto what precisely is at stake when we seek to renegotiate political identity: the paradox of politics.

As Honig explains, the paradox of politics, while often referred to as the paradox of founding, is "much more than that, for it is alive at every moment of political life and not just at the origins of a regime. ${ }^{63}$ The paradox marks the instability and indeterminacy of the people, as such; that is, the flux of any demos that would legislate for itself and, through that legislation, come to assert its existence as a coherent political community in the first place. This bind tracks closely the short circuit I articulated above: attachment to a demos (constitutional patriotism) requires the democratic constitution of the demos as such, which itself presupposes the very same original attachment. Put simply: 'In order for there to be a people well-formed enough for good law-making, there must be good law for how else will the people be well-formed?'4

62 Balibar (n 37) 161.

63 Bonnie Honig, 'Between Decision and Deliberation: Political Paradox in Democratic Theory' (2007) 101(1) American Political Science Review 1, 3.

64 ibid. 
In structural terms, and relevant to our present inquiry, the paradox of politics is a characteristic dilemma for modern democratic politics, in general, and for European politics, in particular, precisely because of the complicated immigration, migration, cultural, and political shifts within a diverse society. Not only a question of birth and death, of coming and going, the paradox of politics marks the reinterpellation of citizens into the institutions and political cultures of a particular polity, a process not directly willed by those citizens themselves. ${ }^{65}$ Is this civic interpellation not precisely what is at stake when we speak of European enlargement and European integration? Is this not our exact concern when we attempt to articulate new supranational political identities for citizens of European nation-states?

The paradox 'attaches to democratic politics as such partly because the people are never so fully what they need to be (virtuous, democratic, complete) that a democracy can deny credibly that it resorts to violence, imposition, or coercion to maintain itself' ${ }^{66}$ In a peculiar way, therefore, 'the people' are an entity simultaneously absent and present, and for this reason democratic politics must continually 'call them into being, rhetorically and materially' while recognising that this call invariably fails and must be repeated. ${ }^{67}$ The people as political subjects are thereby always split, never occupying a stable political space, 'never quite the cause because also always the effect of political practice'. ${ }^{68}$ Thus, the work of democratic politics must always already begin in media res, deprived of sacred points of origin (historical, cultural or legal).

The would-be solution to this paradox is the figure of the lawgiver: Rousseau's external, quasi-mythic founder who sets the law just right so as to enable the self-government of the people. Indeed, is this not precisely the role of the European Court of Justice, the lawgiver that has pushed the processes of integration further than Member States would ever have gone intergovernmentally? Does not the ECJ work to calibrate the material and procedural conditions just right so that, as constitutional patriotism would hope, Europeans might embrace new forms of supranational citizenship? To reiterate from above, the ECJ employed the preliminary reference procedure and the doctrines of supremacy and direct effect with stunningly far-reaching consequences. ${ }^{69}$

\footnotetext{
65 ibid.

66 ibid 5.

67 ibid.

68 ibid. Here, Honig quotes a wonderful phrase from Peter Fitzpatrick. In the absent presence of the people, at the paradoxical moment of politics proper, 'time runs widdershins and the present precedes itself. Peter Fitzpatrick, Modernism and the Grounds of Law (CUP 2001) 74 .

69 See, eg, Bruno De Witte, 'Direct Effect, Supremacy, and the Nature of the Legal Order' in P Craig \& G De Burca (eds), The Evolution of EU Law (OUP 1999) 209. ('It is indisputable
} 
But we must be very careful to recognise that the lawgiver is in actuality no solution at all, that the lawgiver enables self-government of the people only by 'compromising their autonomy'. ${ }^{70}$ Indeed, the original paradox of politics remains undisturbed. Even as the lawgiver founds, the people are left with the decision whether to follow, whether to accept the law as it has been given, or to look elsewhere. Popular sovereignty thus always haunts the imposition of law; the questions of legitimacy and autonomy present themselves again and again. Was this not, in fact, the reaction of many constitutional courts faced with an active ECJ asserting expansive powers of judicial review?

Indeed, this paradox is distinctly echoed in the heated debate concerning the European 'no demos' thesis and is, in part, the source of great confusion even within public law. Joseph Weiler famously criticised the inconsistency of the German Federal Constitutional Court's 'Maastricht decision':71

By endorsing the No Demos thesis [the BVerfG] accentuates the gravity of the Democratic Deficit by negating any democratization power which the European Parliament with its present, expanded powers, may yield. And yet, having done so, by approving the Treaty of Maastricht, it willy-nilly gave it a passing bill of democratic health. ${ }^{72}$

The BVerfG thereby privileged and legitimated - in the defence of democracy - what was considered for many years to be precisely the source of the democratic deficit, namely the intergovernmental elements of European law. ${ }^{73}$ Per a 'soft' reading of the 'no demos' thesis, European citizens are caught in between: while the absence of a defined European demos means that supranational institutions must not compromise national democracy, European institutions nevertheless maintain

that the EEC Treaty was a treaty with some strongly innovative features, and one of them was the preliminary reference mechanism which allowed the ECJ courageously to articulate a duty for national courts which may have been (and still is) implicitly contained in other international treaties as well-but there is no court for saying so'.)

70 Honig (n 63) 5.

71 Brunner $v$ European Union Treaty [1993] BVerfGE 89, 155 (12 October 1993), translated in English at [1994] 1 CMLR 57 and [1994] 33 ILM 388.

72 JHH Weiler, 'Does Europe Need a Constitution? Reflections on Demos, Telos and the German Maastricht Decision' (1995) 1 European Law Journal 219-58. See also JHH Weiler, 'The State “über alles”: Demos, Telos and the German Maastricht Decision' (1995) Jean Monnet Center for International and Regional Economic Law \& Justice, Jean Monnet Working Paper No 6/95.

73 Alec Stone Sweet notes the deep irony, as well, writing: 'Had the rules the German Court laid down [in the decision] been enforceable since the beginning, the construction of an EC charter of rights-which the BVerfG itself required in the name of democracy, but which were not a product of an intergovernmental bargain-would clearly have been unconstitutional." Sweet, The Judicial Construction of Europe (n 19) 94. 
increasing power over the lives of citizens, in precisely the name of a new supranational civic body that holds itself as an ideal for democratisation and universal human rights. The articulation of the 'no demos' thesis is thus itself a marker for the fundamental and indeterminate split of the demos, as such. Europe and its courts seem to be caught, as much as its citizens, in a liminal space, unable either to define or to grasp 'the people' to which they nevertheless must always refer.

But must we consider this liminal space a political trap and withdraw to the familiarity of old nationalisms? Instead, we might view, as does Honig, the failure of the lawgiver another way, as only a beginning, an inauguration of contestatory politics. The conceptual shift here is from the juridical founding of Europe to the ultimately political act of its 'constitution' by an indeterminate constituent power. It is a shift from constitutional patriotism to cosmopolitical agonism. The law, insofar as it is given, insofar as it solicits the people, never fully captures them in their totality. They are always a unity and a multitude. The law thus produces 'remnants' and varying interpretations that must be reconciled through politics, through a productive process of democratic contestation. As Honig writes:

The paradox of politics . . calls attention to law's formative powers, its never fully willed role in processes of subject-formation, and the need, therefore, in a democracy, periodically and regularly to subject law to democratization by way of amendment, augmentation, or nullification. ${ }^{74}$

It is this that should animate the vision of European integration and enlargement: an affirmative embrace of the undecidability of the people, a recognition of law as a beginning for politics, and an agonistic democratisation of the law itself. In its generative force, the law continually produces remnants (alternate interpretations, excluded views and groups, particulars escaping the reach of the universal, etc) that, precisely because they are not captured by the law, inaugurate politics proper. In the end, the paradox of politics

points to alternative domains of political work by depriving us of postulated points of origin ... and inviting us to see [how] law and its authors/subjects fundamentally fail to intersect in the present in ways that satisfy independent standards of legitimation. ${ }^{75}$

Here, we might note with Balibar that the promise of European citizenship resides not in the 'passive enjoyment of formal rights' but in the fact that 'European citizens themselves produce, by removing the

\footnotetext{
74 Honig (n 63) 8.

75 ibid 15.
} 
existing obstacles, the conditions of a new belonging - and no doubt, inevitably, the conditions of a nonexclusive belonging in a new sense of the word' ${ }^{76}$ Only in this dynamic sense is the full measure of European citizenship and supranational identity thinkable. In the end, the political identity of a demos is intricately tied to its own inner dynamic of inclusion and exclusion, to coming to terms with its own 'remnants', and to the political negotiation of the defined border it might draw. ${ }^{77}$ It is to this dynamic that I now turn.

\section{Beyond inclusion and exclusion: heterogeneity as European cosmopolitics}

The indeterminacy of the demos, the idea that the self-legislating and sovereign 'people' is always constitutively split, frames the question of political identity as one of contingency and of necessary exclusion, the creation of differential 'remainders'. That is, the identity of the people and their self-presence in the world become a contingent negotiation of the lines of exclusion/inclusion that mark and determine, however unstably, the polity's boundaries. Indeed, in order for the demos to be democratic and civic, as opposed to simply ethnic in strongly essentialist terms, it must internalise this negotiation as part of its own identity. It must 'occupy' the space of indeterminacy. My thesis here is that the European identity - in order to emerge in contradistinction to nationalist particularism while at the same time rejecting an empty and unmotivated universalism - faces precisely this task. Located strictly within the paradox of politics, this task cannot be fulfilled with constitutionalism alone. Rather, law requires a democratic supplement, and indeed this is why Europe's current democratic deficit presents such a fundamental problem and why constitutional patriotism has failed to take broader hold within the European political consciousness. Nevertheless, to push the critique further, this democratic supplement must take a particular form: not simply expanding the margins of inclusion but articulating a new agonism that would think differently about boundaries themselves. Through this renewed contestatory politics, European identity would find productive ways to reclaim a future on behalf of the Other, on behalf of those whom European identity necessarily excludes in the present so that it may exist in the first place. In this sense, European political identity would adopt a distinctly ethical and cosmopolitan dimension: a rethinking of the very idea of integration, of the negotiation of the included

\footnotetext{
76 Balibar (n 37) 162.

77 As Balibar writes, 'We are not 'citizens', but we can 'become' citizens; we can enter into one or several processes of creation of citizenship. And we enter all the more deeply into them the numerous and more different (I would almost say the more divergent) we are'. ibid 199.
} 
and excluded, of inside and outside. ${ }^{78}$ It is only this kind of democracy that can be called cosmopolitan and, in the end, European.

When Étienne Balibar delivered his lecture, 'At the Borders of Europe', in 1999 in Thessaloniki, Greece, he began by noting Greece's place as "one of the "peripheral" countries of Europe in its traditional configuration' ${ }^{79}$ For Balibar, Greece captured both the metaphor and the reality of the border: a place where the 'dialectic between confrontation with the foreigner (transformed into a hereditary enemy) and communication between civilizations (without which humanity cannot progress) is periodically played out'. ${ }^{80}$ At this border, within and across peripheral zones, the confrontation of difference (whether cultural or economic) constitutes the 'melting pot for the formation of a people (demos), without which there is no citizenship (politeia) ${ }^{81}$ Indeed, as this section will attempt to show, the periphery inverts in Derridean fashion to become the centre in the constitution of a European cosmopolitan identity. Balibar writes with words that ring even truer and more imperative today: 'If Europe is for us first of all the name of an unresolved political problem, Greece is one of its centers, not because of the mythical origins of our civilization . . . but because of the current problems concentrated there. ${ }^{82}$ If we indeed take Europe, as an ideal, to represent an unresolved question of politics and of political identity, Greece and all border regions become essential to formulating what is at stake: the posited transformation of civic identity through juridification, economic determinism, as well as the entry of the Other - immigrants, asylum seekers, citizens of accession countries - into the European political community. The reason why the liminal spaces of Europe become drivers of a pan-national European identity lies in the contradictory construction of the people and the conflicts through which such contradictions are navigated, if not resolved. If there really is an 'emergent' European people, then it is to be found at the border of belonging and exclusion, in the very negotiation of identity claims. In other words, the border, more than any other place (both physical and conceptual), makes visible the people's indeterminacy, their constitutive split in its distilled, pure form. Greece is (or, rather, has the potential to be) contemporary Europe's 'Philadelphia' of 1776 or 'Paris' of 1789 - the particular democratic supplement to pan-European constitutional legalism.

78 See, eg, Gerard Delanty, 'The Idea of a Cosmopolitan Europe: On the Cultural Significance of Europeanization' (2005) 15(3) Intl Rev of Sociology 405, 416. ('[S]trengthening democracy alone will not create a cosmopolitanism'.)

79 Balibar (n 37) 1.

80 ibid.

81 ibid 1-2.

82 ibid 2. 
Let me clarify in greater detail why this might be the case. Each of the terms thus far invoked - indeterminacy, undecidability, instability, constitutive split, differential remainder - ultimately refers to the impossibility of representing the self-identity of the demos. These claims about the tensions within political identity, and therefore about its contingent construction, emerge from the tradition of Ernesto Laclau's radical democracy and his concepts of hegemony and heterogeneity. Together, radical democracy, hegemony and heterogeneity provide a productive analytic frame for understanding the task of European supranational cosmopolitanism and of its political practice.

For Laclau, the construction of common political identity functions only through the practice of 'hegemony', by which differences across particularities are rearticulated into a unity. ${ }^{83}$ This unity rests on no essentialism; it is instead a contingent articulation, the result of political engagement. 'Hegemony is always achieved, never given'. ${ }^{84}$ Moreover, hegemonic unity is communicated necessarily by a particular 'representative,' a part nested within the community itself. This would mean, moreover, that the identity of the communal whole must be in the end unstable: it remains the case that the representative part is particular and thereby retains its difference from each other particular element even while standing in for the whole. This instability can be avoided only if the representative is able to empty itself of all differential content, taking the form of an empty signifier. ${ }^{85}$ The empty signifier - 'freedom' or 'democracy', for example - stands in for the communal whole in such a way that no other particular difference competes with it. In other words, the empty signifier interrupts difference, establishing a chain of equivalence across particularities. The representative is thereby able to establish hegemonic unity and determine the clear, antagonistic lines of division constitutive of the community's fullness: the knowledge of who falls within and who falls without, who is for freedom and against it, who is democratic and who is not. ${ }^{86}$

However, here the difficulty becomes the following: the representative's synecdochic gesture can never entirely succeed because the representative is never able to empty itself fully of differential content. There is always a 'differential remainder' of particularity. ${ }^{87}$ The act of representa-

\footnotetext{
83 See generally Ernesto Laclau, Emancipation(s) (Verso 1996) chapter 3.

84 Ernesto Laclau, 'Why Constructing a People is the Main Task of Radical Politics' (2006) 32 Critical Inquiry 646, 672.

85 Laclau, Emancipation(s) (n 83) chapter 2.

86 For an excellent summary of this position, see generally Lasse Thomassen, 'In/exclusions: Towards a Radical Democratic Approach to Exclusion' in L Tonder \& L Thomassen (eds), Radical Democracy: Politics between Lack and Abundance (Manchester UP 2005).

87 See Ernesto Laclau, 'On the Names of God,' in Sue Golding (ed), The Eight Technologies of Otherness (Routledge 1997).
} 
tion takes place in a field already structured by relations of power and exclusion and thus this act must always establish itself at the expense of other particularities. This exclusion may not be evident right away, but the chain of equivalence eventually unravels when it becomes clear that the empty signifier is actually not that empty at all, when 'freedom' of the community as a whole in practice means the freedom of some at the expense of the freedom of others. In other words, the empty universal can only ever occupy a 'place' of fullness and never give that place content.

Further, the differential remainder betrays a constitutive split in the communal identity as produced by hegemonic articulation. The community is always internally divided; its limits are unclear; its borders are in flux. Here, the precise distinction between inclusion and exclusion gives way. ${ }^{88}$ There remains an irreducible gap between hegemony and identity itself - that is, between the temporary 'fullness' articulated by the empty signifier and the universal self-correspondence of the community. The basic notion here, going back to Hegel, is that universality is never purely universal; it is never truly context-transcending and free of particularity. Universalism can only emerge out of particularity, out of an inscribed event already marked by particular exclusions. As Laclau writes, 'Universality is incommensurable with any particularity but cannot, however, exist apart from the particular'. ${ }^{89}$ This mutual relation between the particular and the universal, between the part and the whole, creates a perpetual gap dividing hegemonic articulation and the universal (closed) communal identity. This gap, therefore, must always be renegotiated and rearticulated politically: 'The recognition of the constitutive nature of this gap and its political institutionalization is the starting point for modern democracy'. ${ }^{90}$ I hope to show that it ought to be the starting point for a reappraisal of European cosmopolitan politics, as well.

The term for this residual particularism, the gap that is a condition of (im)possibility for the process of hegemony, is heterogeneity. Heterogeneity is the differential remainder that must be continuously suppressed in order for the hegemonic articulation to survive in its current terms. Yet, without heterogeneity, the equivalence made across differences and the logic of division would be impossible. The exclusion of the heterogeneous enables us, in the first place, to speak of an inside and outside. In the very process or moment of suppression, identity and difference emerge as sensible. Thus, heterogeneity refers to that which eludes yet constitutes the logic of inclusion and exclusion. ${ }^{91}$ It bestrides the very

\footnotetext{
88 See Thomassen (n 86) 107.

89 Laclau, Emancipation(s) (n 83) 34.

90 ibid 46.

91 Thomassen offers a clear example of such heterogeneity: the figure of the Lumpenproletariat in Marx. 'The Lumpenproletariat is a discursive excess, escaping the conceptual
} 
limits of political identity. This is why the heterogeneous element is so critical to our inquiry: its continued presence lifts the veil on the wider issue of political belonging, on the whole question of the logics that structure the social and political whole as whole..$^{92}$ Heterogeneity is the symptom of a much broader and deeper phenomenon of exclusion.

Focusing on such discursive remainders, the loci of heterogeneity, thereby enables us to criticise from within the existing marginal determinations of identity. By destabilising the division itself, heterogeneity disrupts previously settled sites of communal identity. Put simply, heterogeneity is the marker of contingency; it is evidence for the fact that a particularly constructed identity, with its limits and delineations, could be otherwise. For this reason, the work of heterogeneity is the cosmopolitan political operation par excellence. ${ }^{93}$ Indeed, if our ideal of European cosmopolitanism demands the disruption of closed national identities and the development of new forms of belonging and corresponding legal structures, then Europe's heterogeneous elements provide a promising analytic and symbolic starting point. Heterogeneity enables us to work beyond the abstract hollowness of current pan-European ideals, to fill these empty signifiers with concrete meaning embedded in concrete struggles. Moreover, heterogeneity confronts directly the current borders of exclusion lining the European political space. ${ }^{94}$

In this sense, the heterogeneous frame centres a particular vision of cosmopolitanism itself; namely, cosmopolitanism conceived not as a European (or, for that matter, global) super-state, merely re-inscribing the exclusionary logics of the nation-state on a larger scale. Instead of attempting to overcome exclusion through an a priori 'universally' inclusive state, heterogeneity demands a new form of cosmopolitics that reconsiders which exclusions are made, how, and by whom. This Euro-

categories of the analysis of capitalism. It is heterogeneous to these categories, a discursive remainder from the determination of the antagonistic relation between the proletariat and the capitalist class. However . . . the Lumpenproletariat not only shows the limit of the attempt to objectify the relation between proletariat and capitalists; it is the exclusion of the Lumpenproletariat from the other conceptual categories that makes Marx able to theorise the latter as determined by their antagonistic opposition'. Thomassen (n 86) 113.

92 See Laclau, 'Why Constructing a People is the Main Task of Radical Politics' (n 84) 667.

93 Heterogeneity exemplifies a particularly ethical vision for the cosmopolitan project. It is an orientation and frame of mind towards politics fitting with the following reflection by Edward Said: 'I occasionally experience myself as a cluster of flowing currents. I prefer this to the idea of a solid self, the identity to which so many attach so much significance. These currents, like the themes of one's own life, flow along during the waking hours, and at their best, they require no reconciling, no harmonizing. They are "off" and maybe out of place, but at least they are always in motion, in time, in place, in the form of all kinds of strange combinations moving about, not necessarily forward, sometimes against each other, contrapunctally yet without one central theme'. Edward Said, Out of Place (Granta 1999) 295.

94 See Balibar (n 37) 9. 
pean cosmopolitics would understand exclusions to be necessary but contingent, and thereby always already open to contestation.

Furthermore, because the inclusion of some relies on the suppression and exclusion of others, cosmopolitics as heterogeneity must question the dominant models of inclusion, as well. As Lasse Thomassen writes, 'If exclusion is constitutive of inclusion, then inclusion cannot simply proceed as the extension of symmetrical relations to a point where we reach universal inclusion'. ${ }^{95}$ Instead, we must find new ways to understand and relate to those who are, at the moment, excluded. In this vein, Thomassen expresses concern with Robert Goodin's call for the expansion of institutional frameworks to accommodate belonging beyond the nation-state: 'a system of multiple, overlapping "sovereignties", with lots of different levels and places one might lodge an application or an appeal', as well as other institutions to care for those still falling outside the reach of these 'sovereignties'. ${ }^{96}$ Is this not, by the way, almost identical to the constitutional pluralist model envisioned by some for the European continent, a mélange of national constitutional courts operating in overlapping and interpenetrating universes with the European Court of Justice and the European Court of Human Rights, offering a variety of fora in which to lodge appeals? ${ }^{97}$ While Goodin recognises the constitutive exclusion at work here, the problem is that those offered residual inclusion remain marginal and thus nearly as excluded as before. ${ }^{98}$ Precisely because of the intertwined nature of inclusion/exclusion and the blurring of boundaries, those who remain (who fall outside the reach of these

95 ibid 115.

96 Robert Goodin, 'Inclusion and Exclusion' (1996) 37 Archives Européenes de Sociologie 364.

97 See Neil Walker, 'The Idea of Constitutional Pluralism' (2002) 65 Modern Law Review 317; see also Neil MacCormick, Questioning Sovereignty: Law, State and Nation in the European Commonwealth (OUP 1999) 117 (constitutional pluralism entails that '[t]he legal systems of member-states and their common legal system of EC law are distinct but interacting systems of law, and hierarchical relationships of validity within criteria of validity proper to distinct systems do not add up to any sort of all-purpose superiority of one system over the other'.); Mattias Kumm, 'Who is the Final Arbiter of Constitutionality in Europe?: Three Conceptions of the Relationship between the German Federal Constitutional Court and the European Court of Justice' (1999) 36 Common Market Law Review 351; Mattias Kumm, 'The Jurisprudence of Constitutional Conflict: Constitutional Supremacy in Europe Before and After the Constitutional Treaty' (2005) 11 European Law Journal 262; Miguel Poiares Maduro, 'Contrapunctual Law: Europe's Constitutional Pluralism in Action' in Neil Walker (ed), Sovereignty in Transition (Hart Publishing 2003) 501; Miguel Poiares Maduro, 'Interpreting European Law: Judicial Adjudication in a Context of Constitutional Pluralism' (2007) 1 European Journal of Legal Studies 1; Julio Baquero Cruz, 'The Legacy of the Maastricht-Urteil and the Pluralist Movement' (2008) 14 European Law Journal 389; Armin von Bogdandy, 'Pluralism, Direct Effect, and the Ultimate Say: On the Relationship Between International and Domestic Constitutional Law' (2008) 6 International Journal of Constitutional Law 397.

98 See Thomassen (n 86) 116. 
multiplying institutions) will be scattered in all forms of liminal spaces inside and outside, relegated to marginal positions as residual. At work here seems to be a comfortable gradualism quite unable or reluctant to engage more critically the dominant logic of inclusion itself.

To the appraisal of Goodin's framework should be added similar enthusiasms for embracing the productive cosmopolitan capacity of socalled 'disaggregated citizenship' currently at work to varying degrees in the European Union. ${ }^{99}$ Seyla Benhabib has noted with approval the granting of privileges of political citizenship to residing EU citizens irrespective of particular European nationality: namely, the rights to vote and stand for office in local elections, as well as more substantial socioeconomic rights for longer-term residents. ${ }^{100}$ Benhabib recognises that the situation is much less agreeable for third-country nationals, who do not have the benefit of these political rights, yet points to (apparently unidirectional, linear) changes in Denmark, Sweden, Finland, and Holland, where even third-country nationals can participate in local elections. ${ }^{101}$ She nevertheless asserts, 'The most important conclusion to be drawn from these developments is that the entitlement to rights is no longer dependent on the status of citizenship. ${ }^{102}$ While democratic cosmopolitics might see the promise of such moves of inclusion, we might also be more careful to note the hidden exclusions and marginalisations on which these inclusions depend. This is especially true in the case of third-country nationals and the provision of social rights, a situation we currently see deteriorating in times of deep economic recession. ${ }^{103}$

Thus, while Benhabib might view the continued inner exclusion of immigrants as a postscript to be resolved through time and through further democratic iterations of constitutional rights, we might disagree. Instead, we might assert with Balibar that 'this question of the interior exclusion of "immigrants" constitutes a genuine test of truth for the nation-form and for the "community of citizens" to which it gives a name'. ${ }^{104}$ We might point to the "gaps [that emerge] in the content of European rights, official practices that diverge significantly from formal legal obligations, and the limited extent to which individuals try to exercise these rights that transgress traditional boundaries between national societ-

\footnotetext{
99 See, eg, Jean Cohen, 'Changing Paradigms of Citizenship and the Exclusiveness of the Demos' (1999) 14(3) International Sociology 245.

100 Benhabib, Another Cosmopolitanism (n 49) 46.

101 ibid.

102 ibid.

103 See, eg, Lisa Conant, 'Contested Boundaries: Citizens, States, and Supranational Belonging in the European Union' (2001) Robert Schuman Centre for Advanced Studies, European Forum Series, RSC No 2001/21.

104 Balibar (n 37) 61.
} 
ies'. ${ }^{105}$ Here, the question becomes whether such interior exclusion, far from being a sphere yet to be included, is rather a symptom of the very programme of inclusion - namely of its legalistic character - to which we are currently committed. ${ }^{106}$

Indeed, even the most recent appeal by Jürgen Habermas for a shared sovereignty between European nation-states and supranational institutions threatens the creation of new gaps in which citizenship and rights fail to accrue. ${ }^{107}$ In these gaps, individuals become once again exposed without the protection of a political community. It is in precisely these spaces that the heterogeneous element is made visible, as such. Is this not what happened to the Greek voter, for example, whose voice was all but silenced (despite all forms of political and civic rights) before the decision of the EU organs and Council of Ministers to push forward the conditioned bailout of the Eurozone? ${ }^{108}$

The relevant point here and in response to Goodin is that, if we as Europeans are to be responsible to the call of cosmopolitics, we must orient ourselves to the concrete practices of marginalisation that occur even within moves towards greater formal inclusion under the law. Even here, new boundaries and limits are redrawn, sometimes re-emphasised. In this sense, cosmopolitics is an orientation to marginalisation in the precise meaning of the term, occurring at the margins, in the liminal spaces that never fail to reassert themselves. Because heterogeneity orients us both to the contingency behind current states of affairs and power arrangements, as well as to the boundaries of the political community itself, a cosmopolitics of heterogeneity prompts us to rethink altogether the ways in which our communities constitute themselves. ${ }^{109}$

\footnotetext{
105 Conant (n 103) 1.

106 Balibar has conceived this inner relationship as one between (a) the development of the European Union and its search for a political identity and (b) the creation of a new European 'apartheid', in which new groups of immigrants and poor of various nationalities are excluded and discriminated against within the borders of Europe. Balibar (n 37) 31-50.

107 See Habermas, On Europe's Constitution (n 22).

108 See, eg, 'One Step Closer to Nowhere' To Ethnos (Athens 13 February 2012) <http:// www.presseurop.eu/en/content/article/1506381-one-step-closer-nowhere>; Frank Shirrmacher, 'Democracy Has Junk Status' Frankfurter Allgemeine Zeitung (Frankfurt am Main 2 November 2011) <http://www.presseurop.eu/en/content/article/1128541-democracy-has-junk-status>; Giorgos Malouhous, 'Greece Retires...' To Vima (Athens 9 February 2012) <http://www.presseurop.eu/en/content/article/1495071-greece-retires>; Rainer Hank, 'Greece, the Serf of Europe' Frankfurter Algemeine Sonntagszeitung (Frankfurt am Main 17 June 2011) <http://www.presseurop.eu/en/content/article/719681-greece-serfeurope>; Amartya Sen, 'Let's Wrest Democracy Back' The Guardian (London 24 June 2011) <http://www.presseurop.eu/en/content/article/737641-amartya-sen-lets-wrest-democracy-back> all accessed 10 June 2012.
}

109 See Thomassen (n 86) 116. 
In this regard, the rethinking of boundaries remains sceptical of our ability to ever abolish exclusion, indeed, remaining mindful of the exclusion that conditions any inclusive endeavour. Cosmopolitics thereby attempts to walk a fine line, rejecting the false choice often posed to us. As Bonnie Honig eloquently puts it:

The challenge is to open up room for the much-needed double gesture: for example, to oppose the constitutionalization of the EU in the name of an alternative locatable and accountable rule of law, to counter that future with another in the name of the very democratic and human rights that constitutionalization has historically claimed to entrench, and to do all this without being cast as a mere agonist, or a defender of national particularity, or as a member of the $\mathrm{Na}$ tional Front, as if these were the only options. ${ }^{110}$

This conceptual middle again finds its expression in the limit situations in which the foreigner must be brought within the public sphere of participation. Since heterogeneity always structures the community's capacity to define itself coherently, the heterogeneous element's traversal of the communal boundary presents the purest opportunity for the polity's cosmopolitical self-appraisal, for it to destabilise and thereby paradoxically reconstitute its 'common' identity. It is at this moment that the community as such is self-present, that it intersects - fleetingly - with the universal.

This point is nicely captured by Jacques Rancière's analysis of the 'part with no part': a body included as a subset of the community only insofar as its existence is suppressed so that the dominant identity-formation can proceed through hegemonic power. ${ }^{111}$ In Disagreement, Rancière argues that politics - in contradistinction to mere administration, domination, or police - exists 'when the natural order of domination is interrupted by the institution of a part of those who have no part. This institution is the whole of politics as a specific form of connection. It defines the common of the community as a political community'. ${ }^{112}$ It is, in short, the assertion of equality amidst a field of inequality. Thus, the properly political act - that is, the act that founds the community as a political entity - does not merely extend the status of victim to the excluded or include them as marginal figures within still new structures of

\footnotetext{
110 Bonnie Honig, 'Another Cosmopolitanism? Law and Politics in the New Europe' in Robert Post (ed), Another Cosmopolitanism (n 50) 114.

11 Critical to this concept is a revival of Hannah Arendt's assertion that the refugee is the paradigm for conceptualising politics and the contemporary state. See Hannah Arendt, 'We Refugees' (1943) 31(1) Menorah J; see also Giorgio Agamben, 'We Refugees' (1995) 49(2) Symposium 114.

112 Jacques Rancière, Disagreement Politics and Philosophy (Julie Rose tr, University of Minnesota Press 1999) 12.
} 
subordination. Rather, the political act reconstitutes the community as a whole, the community's universal quality, by 'making "a part of those who have no part," or by giving an unconditional right to the discourse of equality whose bearers they are historically.' ${ }^{113}$

I would therefore suggest that the constitutive European political act occurs through subjectification in the course of including the part with no part; in the giving of priority to the political rights and political struggles of the marginalised part at the boundary of inclusion and exclusion. This political subjectification, in which individuals begin to see themselves as citizens constituting a new political body, is the element absent from Europeanisation through European Union law. Because subjectification occurs within or in reaction to the spaces of heterogeneity, the law - insofar as it must unify heterogeneous cases under classification and doctrine - obscures precisely these sites of meaning-creation. ${ }^{114}$ Thus, in elaborating (with Laclau) a radical democratic conception of European identity, we must begin not with a positive constitutional law but with the site of the 'wrong' itself, the site of marginalisation. The political subjectification of European citizens occurs in the shared act of making this wrong right. ${ }^{115}$

Therefore, if Europe is to continue as a supranational and cosmopolitan project while at the same time remaining democratic and legitimate as a political community, its constitutive founding moment lies in the "confrontation with the different modalities of exclusion'. ${ }^{116}$ It is here that European citizenship might (for nothing is guaranteed) be born. The shared act requires dominant and subaltern groups to be brought together, to participate in the same political struggles. ${ }^{117}$ The critical point here is that - by privileging cross-cutting participation in political struggle and therefore recognising excluded groups as active citizens even before

\footnotetext{
113 Balibar (n 37) 72.

114 In collapsing distinctions and creating new equivalences, law suppresses heterogeneous elements as heterogeneous. This process functions with simple naming of the Other ('immigrant' or 'migrant' or 'third-country national'), in terms dictated by dominant discourses, or it works in the more complex objectification through the discourse of rights that codify different existing modalities of subordination. See, eg, Wendy Brown, States of Injury: Power and Freedom in Late Modernity (Princeton UP 1995). Moreover, in the EU context, this is also why economic integration is particularly ill-suited for the task of crossing-boundaries while preserving heterogeneity: insofar as economics asserts equivalence across previously closed social sites, it falls into the same short circuit of abstraction as does law.

115 See Balibar (n 37) 74-5.

116 ibid 76.

117 For this, of course, appeal to abstract principles and rights must be supplemented by strong appeals to passion and to sentiment. Nevertheless, these concrete political struggles, in addition to being the 'moments of truth' for political identity, are also the testing and proving grounds for the motivational participatory identities that ultimately sustain democratic life. See below section 2 .
} 
they are granted formal rights to citizenship - the chain of transnational cosmopolitics is brought into being through anticipation. ${ }^{118}$

As we shall see, this concept of heterogeneity allows us to intervene in current debates about European immigration, asylum, and nationality. It allows us to see them as sites for the creation of a cosmopolitan European political identity, as the refugee becomes the subject of European politics proper.

\section{The refugee as citizen: migration and nationality in the new Europe}

The processes of EU enlargement and internal integration have recast the borders of the continent. The polemicised Fortress Europe and its treatment of asylum seekers and refugees parallels the internal divisions within the Union and the new social exclusion of 'internal refugees'. The concern here is thus double: the right of entry into the Union, understood as an ethically significant act of hospitality, ${ }^{119}$ as well as the internal struggle for political and social rights by marginalised groups, understood as the struggle for equality against structures of subordination and domination. The sites of division recur both at the external borders of Europe, as well as in new places altogether - within cities (centre/peripheral suburbs); across religious communities (secular/Muslim/Jew/Catholic); and across regions (with depressed/advanced rates of economic growth). Whatever the site, however, each of these coalesces around the exemplary figure of the migrant-refugee, the model for how we might conceive citizenship if we are to build a polity beyond the logics of inclusion and exclusion.

As mentioned above, the focus on the refugee prompts an important change of analytic frame that enables us to see the reach of a new European sovereignty to be democratised. While sovereignty has transformed its relationship to hospitality, this shift is not in itself definitively positive. As Honig is careful to emphasise, 'new openness . . . can just as well be a sign of sovereignty's adjustments, accommodations, and relocations' from traditional and visible locales to those new and less visible. ${ }^{120}$

\footnotetext{
118 See Étienne Balibar, 'At the Borders of Citizenship: A Democracy in Translation?' (2010) 13(3) European Journal of Social Theory 315, 320.

119 See Jacques Derrida, Of Hospitality (Rachel Bowlby tr, Stanford UP 2000). Derrida argues that to ask the question of Europe is to bring to mind and to cultivate a culture of hospitality, an ethos of belonging, and-in the end-an ethics. Derrida writes, '[I]nasmuch as it is a manner of being there, the manner in which we relate to ourselves and to others, to others as our own or as foreigners, ethics is hospitality; ethics is so thoroughly coextensive with the experience of hospitality', ibid 123-5.
}

120 Honig, 'Another Cosmopolitanism?' (n 110) 114. 
The question thus becomes the following: 'What if refugees, rather than (or in addition to) being the exceptions of the juridical state (or continental) system, are metaphorically its norm, the exemplary objects of the sort of power that the state system and its sovereign legalism represent but hide?'121 I want to take this point even further. As I will suggest, refugees are not only the exemplary objects of the new European sovereignty but also the exemplary subjects of a new European politics, perhaps precisely because of their liminal status. The figure of the migrant-refugee - those both excluded from and within Europe - is directly implicated in the processes whereby Europeans, those that consider themselves included in the polity (or polities) of Europe, might regain their own citizenship, might become citizens themselves.

Here, I want to stress the confluence of the preceding abstract considerations of citizenship (universality/particularity, the indeterminacy of 'the people', sovereignty, constitutionalisation) and the more concrete matters of residency permits, short-term and long-term visas, issues of family reunification, and so on. Again, if we consider citizenship's evolution into the sphere of the supranational to be critical for the existence of a truly democratic Europe, then the status of 'the foreigner' or 'the immigrant' within the European political space is intimately bound up with the democratic freedoms of all other European citizens. Indeed, the inclusion of the Other in this sense overlaps with the successful traversal of citizenship from a merely national affair to a concept with supranational meaning and import.

The obstacle such a traversal faces is the clear asymmetry of the immigrant worker or the refugee before the 'native' society, into which he nevertheless might be considered 'integrated'. The immigrant as non-national is extended the formal protections of all sorts of juridical rights, yet is nevertheless kept in a 'status of legal tutelage'. ${ }^{122}$ He receives the tools for assimilation, even successful assimilation, yet the process whereby he may become 'one of us' is 'only on the condition of respecting the terms of a "contract" whose terms he can never negotiate for himself'. ${ }^{123}$

This form of conditional hospitality a priori structures the encounter in the native host's favour. As Jacques Derrida writes, the stranger 'must ask for hospitality in a language which by definition is not his own, the one imposed on him by the master of the house, the host, the king, the lord, the authorities. ${ }^{124}$ As we shall see, this is captured in the

\footnotetext{
121 ibid 115.

122 Balibar, We, the People of Europe? (n 37) 40.

123 ibid.

124 Derrida (n 119) 15.
} 
legal language through which the right to asylum, its adjudication, and its policing are governed. As such, limited hospitality is predicated on the preservation of a boundary, not its transcendence or reappraisal. Nevertheless, this hierarchy is precisely also an opportunity, insofar as the gap between the national and non-national makes visible the contingency of all other discriminatory social relations within a particular polity. It is within and in response to this gap that a supranational citizenship might emerge.

Let us briefly outline how such a gap appears in the context of European citizenship before considering the issues of immigration and asylum. The Treaty of Maastricht directly extended European citizenship only to nationals of existing European Union Member States and thus plainly excluded from political citizenship the many people coming in from non-European countries (namely the immigrants from places like Turkey, India, Algeria, Morocco, and China), regardless of their cultural or economic integration within European society. ${ }^{125}$ For nationals of nonMember States, their access to political rights remains entrenched in their extra-European cultural and national origins. Thus, the facially progressive move to decouple political citizenship in the European Union - the rights to vote in local elections or to petition European tribunals - from national belonging introduces a new form of discriminatory exclusion previously unknown in the nation-state. ${ }^{126}$ Now, the foreigner is no longer a bearer of rights under another, reciprocal national sovereign; he is instead a lesser citizen within the boundary of a new (additional) supranational order. He is the object of internal exclusion. Balibar puts this in razor sharp terms: the third-country nationals,

installed for one or several generations on the soil of the various European countries, and who as a whole have become indispensable to European well-being, culture, and civility, become a mass of second-class citizens or subject residents 'at the service' of Europeans by full right, even when they enjoy long-term or permanent rights of residency. ${ }^{127}$

The imposition of this seemingly permanent hierarchy produces the symptomatic outcome of framing new forms of discrimination within European society, around which nationalist sentiments of racist xenophobia can accrue. It is no surprise then that political discourse in Europe, especially preceding national elections, tends to incorporate strong anti-

\footnotetext{
125 Consolidated TEU (n 33) art. 9 ('Every national of a Member State shall be a citizen of the Union. Citizenship of the Union shall be additional to national citizenship and shall not replace it').

126 See Balibar, We, the People of Europe? (n 37) 44.

127 ibid.
} 
immigrant rhetoric and vague talk of repressing illegal immigration. ${ }^{128}$ The cynical paradox should be noted, too, as third-country nationals are excluded from full political participation in their communities yet very readily included in the economic systems in which quality of life and salary level differences can still be exploited.

The main point here is that, even when read most sympathetically, the European Union is the site of a double, divergent movement in which (a) formal rights of European citizenship are gradually extended to include certain classes of third-country nationals in the European legal order, while (b) Member State governments constrict national citizenship policies in order to limit access to those same EU citizenship rights. ${ }^{129}$ The European Court of Justice has sharpened its position, all but terminating national linkage under EU law and extending equal rights to all EU residents, ${ }^{130}$ as well as developing a complex line of cases on equal

128 Take, for example, the recent remarks by French President Nicolas Sarkozy on his in-
tentions to end illegal immigration, to the point of possibly dismantling the Schengen space
itself. See 'Sarkozy Threatens to Withdraw from Schengen Accord' BBC News (London 11
March 2012) <http://www.bbc.co.uk/news/business-17332458> accessed 10 June 2012 .
This is not to mention the continuous anti-immigrant rhetoric of LePen's National Front, or
the recent controversy surrounding the Dutch People's Party (PVV) website urging citizens
to submit complaints about migrant workers from Central and Eastern Europe. That such
discriminatory attitudes have taken hold in what are traditionally seen as the most progres-
sive of European states should give us pause. Further, we should look at the handful of
countries (France, Netherlands, Italy, Belgium, and others) that have already banned or are
entertaining proposals to ban the wearing of the burqa in public. See, eg, Loi No. 2010-1192
interdisant la dissimulation du visage dans l'espace public [Law Forbidding the Conceal-
ment of the Face in the Public Space] of 11 October 2010, Journal Officiel de la République
Française [JO] [Official Gazette of France] (12 October 2010) 18344; Loi visant à interdire le
port de tout vêtement cachant totalement ou de manière principale le visage [Law Forbid-
ding the Wearing of Face-Concealing Clothing] of 1 June 2011, Moniteur Belge [MB] [Official
Gazette of Belgium] (13 July 2011) 41734. 129 See, eg, Case 200/02 Kinqian Catherine Zhu and Man Lavette Chen $v$ Sec'y of State for the Home Dept [2004] ECR I-09925 (extending EU citizenship rights, namely the right of residence, to the parents of a child born in Ireland and thus attaining Irish citizenship). This case is particularly exemplary of the divergence in EU and national law. After Chen and other similar cases, Irish voters approved in 2004 by referendum an amendment to the Irish Constitution that made it possible for the government to deny citizenship to children born in Ireland without at least one Irish parent. See Dail Debates, Vol 583, No 6 (21 April 2004).

130 See, eg, Case 370/90 The Queen v Immigration Appeal Tribunal and Surinder Singh [1992] ECR I-4265; Case 291/05 Minister voor Vreemdelingenzaken en Integratie $v$ R. N. G. Eind [2007] ECR I-10719; Case 127/08 Blaise Baheten Metock and Others $v$ Minister for Justice, Equality and Law Reform [2008] ECR I-6241. Furthermore, Directive 2003/109/EC addresses the status of long-term resident third-country nationals in the European Union and provides that 'the legal status of a third-country national should be approximated to that of Member States' nationals and that a person who has resided legally in a Member State for a period of time to be determined and who holds a long-term residence permit should be granted in that Member State a set of uniform rights which are as near as possible to those enjoyed by citizens of the European Union'. Council Directive (EC) 2003/109 of 25 November 2003 concerning the status of third-country nationals who are long-term resi- 
treatment in relation to social assistance. ${ }^{131}$ Nevertheless, just as EU organs have recalibrated the scope of European citizenship rights, ${ }^{132}$ the Member States have reserved for themselves an almost indisputable prerogative as gatekeepers for these rights. ${ }^{133}$ This prerogative has been coupled with a constriction of national citizenship policies, both in direct contravention or failed implementation of EU regulations, as well as in tendencies of exclusion and discrimination in areas still under the sole competence of national governments. ${ }^{134}$

The gap between the national and non-national, however, emerges most sharply in the case of the 'would-be' European, the refugee or asylum seeker, against whom the European Union has erected dehumanising and often violent edifices of exclusion. Immigration and asylum procedures of the EU over the past two decades have been steadily criticised as in breach of the European Convention on Human Rights and other

dents [2004] OJ L16. With the acquisition of long-term residency, therefore, TCNs should secure the right of equal treatment in employment, education, access to social security and to tax benefits, as well as protection against expulsion.

131 See Case 85/96 María Martinez Sala v Freistaat Bayern [1998] ECR I-2691. But see Case 158/07 Jacqueline Förster v Hoofddirectie van de Informatie Beheer Groep [2008] ECR I-8507.

132 More recently, on 13 December 2011, the European Parliament and Commission adopted the Directive on a single application procedure for a single permit for third-country nationals to reside and work in the territory of a Member State and on a common set of rights for third-country workers residing in a Member State. Directive (EU) 2011/98 of the European Parliament and of the Council of 13 December 2011 on a single application procedure for a single permit for third-country nationals to reside and work in the territory of a Member State and on a common set of rights for third-country workers residing in a Member State [2011] OJ L343/54. The Single Permit Directive, while positive, presents merely a 'small step forward in EU legal and labour migration' with limited scope (no less than twelve categories of people are excluded) and unambitious levels of harmonisation with significant margins for derogation and manoeuvre at the national level. European Policy Centre, 'EU Single Permit Directive: A Small Step Forward in EU Migration Policy,' Policy Brief, 24 January 2012 <http://www.epc.eu/documents/uploads/pub_1398_eu_single_permit_directive. pdf> accessed 10 June 2012.

133 See Case 135/08 Janko Rottman v Freistaat Bayern [2010] ECR I-1449.

134 For example, EU Member States have generally failed to transpose effectively the Citizens' Rights Directive, requiring supplementary supporting materials and producing substantial processing delays. See, eg, Sergio Carrera \& Anais Faure Atger, 'Implementation of Directive 2004/38 in the Context of EU Enlargement: A Proliferation of Different Forms of Citizenship?' (2009) Centre for European Policy Studies Special Report; A. Hunter, 'Family Members: An Analysis of the Implementation of the Citizens' Directive in UK law' (2007) Journal of Immigration, Asylum \& Nationality Law. The European Commission itself lamented in a December 2008 implementation report: 'The overall transposition of Directive 2004/38/EC is rather disappointing. Not one Member State has transposed the Directive effectively and correctly in its entirety. Not one Article of the Directive has been transposed effectively and correctly by all Member States'. Report from the Commission to the European Parliament and the Council of 10 December 2008 on the application of Directive (EC) 2004/38 on the right of citizens of the Union and their family members to move and reside freely within the territory of the Member States [2008] COM 840. 
UN Conventions on civil and human rights. ${ }^{135}$ The Schengen Convention and the Dublin II Regulation together present European law's focus not on the free movement of individuals but rather on its control and surveillance. ${ }^{136}$ The determination of rights to asylum and the processing of migrants remain astride the grey area where lawful conduct ends and criminality begins and where insufficiencies of legal process invite the discretion of police power. Indeed, the Meijers Commission and many academics have criticised the Schengen Convention for its lack of accountability to either parliamentary or judicial organs, ${ }^{137}$ though - with the entry into force of the Lisbon Treaty - these concerns have been (at least in principle, if not in practice) to an extent allayed. ${ }^{138}$

The Dublin II Regulation is intended to determine the EU Member State responsible for examining a claim to asylum under the Geneva Convention and the EU Qualification Directive. ${ }^{139}$ The European Council on Refugees and Exiles (ECRE), the United Nations High Commissioner for Refugees (UNHCR) and human rights groups have condemned Dublin II for failing to protect refugees effectively: procedures under Dublin regularly impede the rights to a fair examination of the asylum claim and to sufficient protection where that claim has been recognised, regularly cause significant delays in the processing of claims, and have particularly harsh effects on families and asylum seekers with special needs. ${ }^{140}$

135 See Ian Ward, 'Identifying the European Other' (2002) 14 International Journal of Refugee Law 219, 229-30.

136 Specifically, the Schengen Information System maintains surveillance of immigrants, migrants, and asylum seekers.

137 See H Meijers (ed), Schengen: Internalisation of Central Chapters of the Law on Aliens, Refugees, Privacy, Security and the Police (Stichting NCJM 1992). See also Elspeth Guild, 'Between Persecution and Protection: Refugees and the New European Asylum Policy' (2000) 3 Cambridge Yearbook of European Legal Studies 169, 197; V Guiraudon, 'European Integration and Migration Policy: Vertical Policy-making as Venue Shopping' (2000) 38 Journal of Common Market Studies 251, 263-4.

138 With the Lisbon Treaty, which entered into force on 1 December 2009, the Charter of Fundamental Rights of the European Union became binding law on all European Union agencies. Immigration authorities' ability to act, therefore, is not unlimited, but rather is bound by the Charter. Article 18 guarantees 'the right to asylum' and Article 4 of the Charter states, '[N]o one shall be subjected to torture or to inhuman and degrading treatment or punishment'. Treaty of Lisbon amending the Treaty on European Union and the Treaty establishing the European Community <http://eur-lex.europa.eu/JOHtml.do?uri=OJ: C:2007:306:SOM:EN:HTML> accessed 10 June 2012; Charter of Fundamental Rights of the European Union, 2000/C 364/01, 18 December 2000, art 6, para 1 <http://www.europarl. europa.eu/charter/pdf/text_en.pdf> accessed 10 June 2012.

139 Council Regulation (EC) 343/2003 of 18 February 2003 establishing the criteria and mechanism for determining the Member State responsible for examining an asylum application lodged in one of the Member States by a third-country national [2003] OJ L 50/1 [hereinafter Dublin II Regulation].

140 See, eg, European Council on Refugees and Exiles, Comments on the European Commission Proposal to Recast the Dublin Regulation, April 2009; UN High Commissioner for 
Moreover, by permitting the uneven distribution of asylum claims among European Member States, Dublin II shifts significant burdens onto the external border areas of the European Union, specifically onto states that are often unable to provide asylum seekers with the necessary protections and are already strained under a backlog of asylum applications and appeals. ${ }^{141}$ This problem, as we shall see, is particularly acute in countries like Spain, Italy, and Greece.

In general, the Dublin II system reveals a decidedly restrictive and defensive posture against seekers of asylum. ${ }^{142}$ Indeed, both Schengen and Dublin II indicate a concession that, despite overarching international human rights concerns and concerted moves toward harmonisation, immigration and asylum policies remain in the functional control of nation-states. That is, far from being viewed through the lens of anything approaching democratic cosmopolitics, these policies are still considered first and foremost matters of national 'security' and criminality. This, of course, has far reaching consequences for the approach of state officials and police. As Ian Ward argues, rather than working to support asylum procedures and facilities with sufficient resources, the policy is instead intended to control and to negate the flows of migration. ${ }^{143}$ It should be noted, too, that in addition to restricting movement by applying the 'one application only' rule, the European Union has formally excluded the category of 'economic refugees' from asylum claims altogether and thus failed to recognise (however minimally) the core of global economic injustice today. ${ }^{144}$

Yet, more than failing to establish a comprehensive regime to accept and to integrate foreigners, including those wishing to work in the EU (admittedly, an ambitious though not impossible task), the European system has relaxed internal border controls and replaced them

Refugees, UNHCR Comments on the European Commission's Proposal for a Recast of the Dublin and Eurodac Regulations, 18 March 2009 <http://www.unhcr.org/refworld/docid/ 49c0ca922.html> accessed 10 June 2012; Human Rights Watch, Left to Survive: Systematic Failure to Protect Unaccompanied Migrant Children in Greece, 11 December 2008.

${ }_{141}$ See Human Rights Council, Mission to Greece Report Submitted by the Special Rapporteur on Torture and Other Cruel, Inhuman or Degrading Treatment or Punishment, Manfred Nowak, 4 March 2011, A/HRW/16/52/Add.4.

142 In 1992, for example, the European Ministers responsible for immigration issues drafted a recommendation to states concerning expulsion practices and, in baffling disregard for civil liberties provisions and in violation of the European Convention, they noted that Member States should enjoy the "power in appropriate circumstances to restrict the personal liberty of people liable to expulsion'. Community Ministers for Immigration, Recommendation Regarding Practices Followed by Member States on Expulsion, SN 4678/92 WG11266, 1 December 1992.

143 See Ward (n 135) 232; see also Jef Huysmans, 'The European Union and the Securitization of Migration' (2000) 38 Journal of Common Market Studies 751, 756-8.

144 See Ward (n 135) 232. 
with a system of detention camps on the Union's reinforced external borders. The prominent harsh treatment and extra-judicial deportation of Albanians from Italy in 1992 is a pattern that today continues across the Mediterranean. ${ }^{145}$ Human Rights Watch and Amnesty International have published several reports documenting the detention practices and human rights violations at facilities in Greece, the Netherlands, and Spain. ${ }^{146}$ Detained irregular immigrants and refugees often must endure hunger, thirst, severe overcrowding, and poor ventilation. Human Rights Watch reporters described a detention camp in Spain:

At times, more than 500 migrants have been kept in a space that the Spanish Red Cross has determined to be designed to accommodate fifty people. Detainees are cut of from the outside world. There are no telephones. Visits are not permitted. Detainees can never leave the premises; they cannot exercise, and have no exposure to fresh air or sunlight. The state of medical care and sanitary conditions in the facilities also raised serious concern, particularly when the volunteer doctors at the facilities suspended their services in protest over the conditions. ${ }^{147}$

The effects of detention are not just physical but also psychological. A detainee, kept for six months in the Netherlands on boats with little ventilation or access to daylight, described psychological trauma: 'Though they may not beat you, the conditions force you into submission; they kill you psychologically'. ${ }^{148}$

Furthermore, the discharge of asylum processing by police constitutes in many instances a violation of international human rights law. ${ }^{149}$

145 See Bruno Nascimbene, 'The Albanians in Italy: The Right of Asylum Under Attack?' (1992) 3 International Journal of Refugee Law 714, 719-20. Giorgio Agamben draws a particularly strong analogy between these detentions of asylum seekers, specifically the Albanians in Italy, and the emergency regime of the camp: 'The stadium in Bari into which the Italian police in 1991 provisionally herded all illegal Albanian immigrants before sending them back to their country, the winter cycle-racing track in which the Vichy authorities gathered the Jews before consigning them to the Germans, the Konzentrationslager für Ausländer in Cottbus-Sielow in which the Weimar government gathered Jewish refugees from the East, or the zones d'attentes in French international airports in which foreigners asking for refugee status are detained will then equally be camps. Giorgio Agamben, Homo Sacer: Sovereign Power and Bare Life (Daniel Heller-Roazen tr, Stanford UP 1998) 174.

146 Human Rights Watch, Statement: The Human Rights Dimension of EU Immigration Policy: Lessons from Member States (2002); Human Rights Watch, Stuck in a Revolving Door: Iraqis and Other Asylum Seekers and Migrants at the Greece/Turkey Entrance to the European Union (2008); Amnesty International, The Netherlands: The Detention of Irregular Immigrants and Asylum Seekers (2008).

147 Human Rights Watch, Statement (n 146).

148 Amnesty International (n 146).

149 Article 31(1) of the 1951 Geneva Convention Relating to the Status of Refugees states: 'The Contracting States shall not impose penalties, on account of their illegal entry or 
In Greece, for example, putting the preliminary asylum process in the hands of police officers without sufficient training to conduct interviews severely undermines the presumption of a legal framework in which asylum seekers are to be given legal information about their rights and asylum procedures. ${ }^{150}$ Asylum seekers are often simply given orders to leave, written in the host country language. The detainee is rarely offered an interpreter or given a translation, even upon being asked to sign documents authorising his or her deportation. ${ }^{151}$ While some of these returntransfers between countries occur officially, there are many accounts of unofficial and illegal 'drops' or 'dumps' of immigrants across the border by police. Human Rights Watch reported that 12,000 third-country nationals were unlawfully deposited by Greek officials beyond the borders with Turkey between 2002 and 2007.152

Over the past several years, asylum seekers and migrants have filed legal challenges in European courts concerning unlawful transfers to other Member States under the Dublin II Regulation ${ }^{153}$ and related forcible returns threatening exposure to ill-treatment. In January 2011, the European Court of Human Rights ruled that Belgium and Greece violated Articles 3 and 13 of the European Convention due to Belgium's expulsion of asylum seekers to Greece, where they would be exposed to the deficiencies of the Greek asylum procedures and to detention under inhuman and degrading living conditions. ${ }^{154}$ Similarly, in December

presence, on refugees who, coming directly from a territory where their life or freedom was threatened in the sense of Article 1, enter or are present in their territory without authorization, provided they present themselves without delay to the authorities and show good cause for their illegal entry or presence'.

150 Human Rights Watch, Stuck in a Revolving Door (n 146).

151 See Human Rights Watch, Statement (n 146); Human Rights Watch, Stuck in a Revolving Door (n 146); Amnesty International (n 146). 'Rather than initiate a deportation procedure and enforce the removal of an undocumented migrant, the Greek authorities' usual practice is to detain the migrants and upon release from detention hand them a paper which tells them to leave the country within 30 days. This 30-day deadline for departure, commonly known as the "white paper", is written only in Greek'. Human Rights Watch, Stuck in a Revolving Door (n 146).

152 ibid.

153 The Dublin II Regulation and its criteria are designed to avoid 'asylum shopping' and to ensure that only one Member State processes each asylum applicant's claim. When a Member State is deemed responsible under Dublin II to examine a particular asylum application but that individual is currently in a second EU Member State, a transfer between the two states must be arranged. Detention is often used to enforce such transfers.

154 MSS $v$ Belgium \& Greece App no 30696/09 (ECHR 21 January 2011). The Court considered the conditions endured by the applicant in the detention facilities to be unacceptable. It furthermore considered that, "taken together, the feeling of arbitrariness and the feeling of inferiority and anxiety often associated with it, as well as the profound effect such conditions of detention indubitably have on a person's dignity, constitute degrading treatment contrary to Article 3 of the Convention'. ibid. The Court also recognised that the applicant's distress was doubtless intensified by the 'vulnerability inherent in his situation as an asy- 
2011, the European Court of Justice ruled that EU Member States have an obligation under Article 4 of the Charter of Fundamental Rights not to transfer asylum seekers where they would risk being subjected to inhuman or degrading treatment and that the transferring state has a responsibility to establish whether the receiving state would be considered a responsible receiving party under the Dublin II criteria. ${ }^{155}$ Additionally, in February 2012, the European Court of Human Rights ruled that Italy violated Articles 3 and 13 of the European Convention in its interception in international waters and forcible return to Libya of 200 Eritrean and Somali migrants. ${ }^{156}$

Nevertheless, rights violations by both national and EU-level agents implementing European asylum and immigration policies persist. European Union border officials and guards from almost all EU Member States continue their involvement in the systematic mistreatment of migrants as part of the operations of Frontex, the European border agency tasked with the management of operational coordination at external borders. Human Rights Watch (HRW) recently published a report on Frontex activities in the Evros region on the border of Greece and Turkey between November 2010 and March 2011..$^{157}$ In that report, HRW documented how Frontex officers facilitated the transfer of migrants to Greek detention centres, in which individuals were exposed to precisely the inhuman and degrading conditions condemned by the European Court of Human Rights. In addition to the deplorable detention conditions, HRW pointed to a serious protection gap, 'including the risk that genuine refugees might not be identified and would be subjected to refoulement.. ${ }^{158}$ The report concluded that Frontex activities in Greece failed to meet the human rights standards of the EU's Charter of Fundamental Rights. ${ }^{159}$ Further, in July 2012, Amnesty International again sharply criticised Italian authorities for continuing to violate the rights of refugees through the clandestine revival of its migration control agreement with Libya (a mere iteration of the very agreement condemned by the European Court of Human Rights in February), 'despite firm evidence that migrants, refugees and asylum-seekers are still subject to serious abuse' on Libyan

\footnotetext{
lum seeker'. ibid.

155 Joined Cases 411/10 NS $v$ Secretary of State for the Home Department and 493/10 ME and Others $v$ Refugee Applications Commissioner, Minister for Justice, Equality and Law Reform (ECJ 21 December 2011).

156 Hirsi Jamaa and Others $v$ Italy App no 27765/09 (ECHR 23 February 2012).

157 Human Rights Watch, The EU's Dirty Hands: Frontex Involvement in Ill-Treatment of Migrant Detainees in Greece (September 2011).

158 ibid 3.

159 ibid 3, 46-51.
} 
territory, including 'arbitrary arrest, indefinite detention, beatings which can amount to torture and exploitation by armed militias'. ${ }^{160}$

There are two points to be made here. First, there is of course the problem of implementing legal norms as articulated by the European Court of Human Rights and the Charter. HRW thus welcomed cautiously the deployment of European Asylum Support Office (EASO) personnel to Greece to assist officials in improving the asylum process conditions, as well as praised moves to establish Fundamental Rights Officers (FROs) within Frontex to aid in detainee rights protection. ${ }^{161}$ In a sense, this seems to be precisely what Goodin has in mind, the expansion of bureaucratic agencies to cover the gaps emerging within protection systems. And yet the worry is that such gaps can never be covered fully, that such gaps are instead constitutive of the system itself. As the HRW report itself notes: 'Just as Frontex has been designed not to make administrative decisions, EASO too is not authorized to make determinations on asylum request [nor does it have] a specific mandate to intervene directly on detention conditions'. ${ }^{162}$ The refugee status determination (RSD) procedure remains in the last instance the ascribed prerogative of EU Member States. A prospective common European asylum policy - while cautiously applauded as a necessary step to improve rights protection in the course of processing asylum claims - will likely remain insufficient in this regard if the entry decision remains within the competence of the nation-state, as such. Despite numerous negative judgments by European courts and continuing denunciations by international rights groups, the constraint of legality on practical decision-making remains confused, weak, and largely ineffectual in response to large migration flows, flows which appear only to grow with time.

\footnotetext{
160 Amnesty International, 'Press Release: EU can't outsource migration control to Libya' (5 July 2012) <http://www.amnesty.eu/en/press-releases/all/0581-0581/> accessed 20 September 2012. It must be noted that, at the time of the writing of this article, the European Parliament's civil liberties committee passed a promising reform package strengthening protections for asylum seekers under the Dublin II Regulation. See Nikolaj Nielsen, 'EU lawmakers reinforce asylum seekers' rights' EUObserver (19 September 2012) <http:// euobserver.com/justice/117604> accessed 20 September 2012. Should it be passed by the plenary at the end of this year, the reform addresses-at least at the formal level of EU law-many of the deficiencies long noted by human rights organisations and criticised by the European Court of Human Rights and the European Court of Justice. ibid. As I elaborate below, however, there are reasons to remain guarded in our optimism concerning the practical efficacy of such a measure. While it of course represents a welcome shift, the reform fails to change in a fundamental sense the underlying structural weakness of EU policy. If this latest tentative step toward a more humane common asylum system is to be commended, it remains critical to emphasise the gaps in implementation and protection that remain at both the practical and conceptual levels.

161 Human Rights Watch, The EU's Dirty Hands (n 157) 16-8.

162 ibid 17-8. See Regulation (EU) 439/2010 of the European Parliament and of the Council of 19 May 2010 establishing a European Asylum Support Office [2010] OJ L132.
} 
Related to but distinct from the problem of implementation, however, is a second, deeper interplay. When we speak of the rights of migrants, we clearly are not only at the borders of the state but also at the limits of the law, at which the sovereign power is able to exercise violence over human beings. As Itamar Mann (incidentally, author of the Human Rights Watch Frontex report) insightfully argues, the suffering of the refugee at the margins of Europe is a result of the disaggregation of sovereignty itself, through which the responsibility of state actors - European and national - is fragmented. ${ }^{163}$ Indeed, coupling underdetermined oversight and facilitation by European agencies with final enforcement by national constabularies functions precisely to obscure, rather than to clarify, administrative accountability. Here, the gaps are recognised not simply to accompany the shift from national to transnational law but rather to be symptomatic of it. That is, the failure here is not exogenous to disaggregation processes but rather written directly into their internal logic.

Thus, while disaggregation may provide the flexibility to extend legal recognition to new and 'post-national' contexts, it simultaneously creates new sites of vulnerability in which sovereignty - in the sense of the extra-legal 'decision' - operates without legality, and in which individuals are exposed to violence without the protection of law. In other words, disaggregation of sovereignty invites the disaggregation (and thus the dilution) of responsibility. Once the links of responsibility have been cut, the Union and its Member States become free to rearrange and juxtapose violence and law selectively, if not altogether arbitrarily. Moreover, this juxtaposition is no longer visible as an act of politics or of political intervention (and therefore contestable as such) but is instead framed as a matter of administration, of bureaucratic implementation only vaguely and elusively correlated to the field of public contestation. While this may be most acute for the treatment of refugees, is this not also the conceptual analogue of EU citizenship's dark obverse, in which political, civil, and social rights no longer accrue within a self-legislating and empowered citizen but rather are scattered across time and space, in which certain classes of individuals are systematically denied certain categories of rights?

Asylum seekers and refugees at the edge of Europe thus encounter the 'border' in its most concrete and potent form: the detention zones, transfer vessels and transit camps in which the conceptual vision offered by Agamben's 'zone of exception' is realised. Full, coherent rights are suspended as individuals are thrust into places and times of dissolution.

163 Personal conversations with the author; see also Itamar Mann, 'The Legal Structure of Europe's Human Rights Crisis: A Preliminary Outline,' informal working paper, Yale Law School, fall 2011. 
Here, law no longer assumes the social-integrative function ascribed to it by the sublime heights of Habermasian discourse theory. Instead, law is unmasked, in instances of greatest tragedy, as a technicality through which the sovereign state may act as it wishes. Individuals may be killed, may die, but may not be sacrificed. ${ }^{164}$ The refugee, at the boundary of banishment and abandonment, is subject to the processes of selection and filtration that the sovereign imposes. The social meaning of his death - a marker of certain communal bonds - simply fails to hold; the social contract is never written.

These exclusions within and at the borders of Europe, if they are allowed to persist, present significant dangers for the success of a supranational, cosmopolitan European project. In these cases, the chauvinism and alienation of nationalism is merely refashioned and repackaged, simply transferred from the intra-Union space to an extra-Union one, where those excluded are now either non-EU citizens or those formally within the EU who nevertheless lack full citizenship, who remain precisely a 'part with no part'. Moreover, the extension of political and social rights itself is orthogonal to the problem of the refugee or the irregular immigrant; their problem will remain unresolved as long as the logic of inclusion/exclusion remains unchallenged. The figure of the refugee will be recreated again and again. To invoke this figure is to think the liberal state against itself, to bear witness to its internal, constitutive failures. European unification thus cannot be achieved without the kinds of democratic surpluses brought into being in the course of confronting and working through these paradoxes of exclusion. The development of this new European philosophy of immigration will, in large part, determine the future course of the Union and whether it will be worthy of its own ideals of democratic cosmopolitanism.

But what, concretely, can be the template for such an alternative? Where are the beginnings, the roots, of the new democratic cosmopolitics to be found? In the EU context, one painful realisation is that economic integration on its own is particularly ill-suited for the task of crossing boundaries in this particular way, by asserting equality on a previously closed regime. Economic integration embraces a short-circuited abstraction that feeds from the logics of equivalence of global capitalism. Here, the Other is elided as Other, and difference is all but erased in its distinctly political forms. The Other is included only insofar as he is a productive-consumptive force and on terms not of his choosing or command. On the other hand, a cross-border, supranational integration - in effect a certain Aufhebung of borders themselves - inheres in the assertion of equality by particular political agents heterogeneous to the exist-

164 See Agamben, Homo Sacer (n 145). 
ing order. In the supranational context, only these are political agents proper; only these can confront the political question in its original, that is to say, contingent, form. The search for such political agents is thus in essence also a reiteration of the search for a European founding moment. Yet, and this is critical, the founding moment is precisely not the assertion of a new supranational whole. It is instead the confrontation of political division, of the boundaries that divide, in the name of those excluded and in search for a political future that presents itself only as indeterminacy, as negativity. It is, first and foremost, a refusal.

If the current phenomenon of the Other's internal exclusion is indeed symptomatic of our legalistic programme of inclusion, and if cosmopolitanism indeed lacks a participatory-political solidarity, then the invocation of the refugee as a heterogeneous element with political agency can be the beginning of a new European identity. The contemporary struggles of refugees and immigrants might become the 'worksites'165 within which concrete political affects can unite, connect and inspire other objects of marginalisation and depoliticisiation. It is for this reason that I gestured above at the idea that Greece - today bearing the confluence of European technocratic governance, EU enlargement, and migratory pressures - might offer Europe its own 'Philadelphia': the concrete, particular moment in which Europe confronts its political divisions in the name of cosmopolitics.

\section{Droit de cité: toward a Europe of democratic cosmopolitanism}

If the peripheral encounter prompts emulation and a broader reappraisal of identity, what will be the contemporary spaces for such a European cosmopolitics, in which a new European political subjectivity can develop? In this sense I welcome the proposal that a proper and promising response to Europe's increasingly histrionic anti-immigrant sentiment should be the assertion of a new European droit de cité: the extension of a full right of immigration, of entry and residency, of hospitality and citizenship to those who are here merely by virtue of the fact that they are here. ${ }^{166}$ As Honig writes:

We can enact droits de cité - by taking people in, harboring them, offering them shelter, finding sympathetic agents of discretionary power who are willing to look the other way - while also risking the re-authorization of law's authoritative institutions by working through them to win papers or amnesty. ${ }^{167}$

\footnotetext{
165 See generally Balibar, We, the People of Europe? (n 37) 172-79.

166 See Honig, 'Another Cosmopolitanism?' (n 110) 118.

167 ibid.
} 
The droit de cite is therefore the practice of symbolic disruption. It is enacted in the channels between the formalism of law and the contingency of its shadow; it anticipates legal change by bringing its practical ethics into being. Moreover, it revives the European city - as opposed to the nation or region - as the site of a new European democratic cosmopolitanism. ${ }^{168}$ The city, seen as a staging area for a new European collective action, for social contestation, reminds Europe of its own traditions of radical democracy. The contemporary European city bridges the local and the global, the particular and the universal, in ways that escape dominant logics of exclusion.

In this respect, the right of citizenship can be reformulated as a right to the city, the right to public space as such. Droit de cite is the most literal articulation of civic solidarity, of carving out a space of intersubjective engagement distinct from either market-driven or state-driven logics. Here, droit de cité entails the symbolic reshuffling of legitimacy and politics. Droit de cité is not a denial of territoriality but rather its redefinition, its reformulation in the name of those excluded. In extending the right of citizenship to one another, the residents of Europe (nationals and non-nationals alike) would recognise their own liminal positions as political subjects, the fact of life that they are always already in contingent arrangements of exodus and refuge, and that redemption from this alienation comes only in reaffirming and recreating new forms of 'beingin-common'. As Agamben himself writes:

The European space would thus represent an unbridgeable gap between birth and nation, in which the old concept of people (which, as is well known, is always a minority) could again find a political sense by decisively opposing the concept of nation (which until now has unduly usurped it). ${ }^{169}$

Here, cries such as 'We are all refugees now!' or even the sincere but hollow testaments of 'We are all Sarajevans now!' from contemporary Europe's painful memory, even these cries can regain meaning. Droit de cité entails that citizens recognise their inner contingency, their inner indeterminacy, and imagine once again that a new politics is possible.

Droit de cité must be carefully distinguished from the mere disaggregation of sovereignty. The European city, in asserting the right to citizenship, is instead precisely the site where sovereignty, in all of its new autonomies and new collectivities, reconstitutes itself once national sovereignty has been dispersed. The city offers the institutional diversity

\footnotetext{
168 Derrida, too, looks to the city as a possible site for the renegotiation of a new cosmopolitanism. See Jacques Derrida, On Cosmopolitanism and Forgiveness (Routledge 2001).

169 Agamben, 'We Refugees' (n 111).
} 
and confluence of local and global pressures from which new forms of collective identity might emerge. ${ }^{170}$ The key move here lies in translating the contestation of particular political identities into questions of civic place, in which the spatial dimension offers a motif for common political resistance against homogeneity in the name of the citizen, for the polis always astride the particular and the universal. In fact, the city - because it must ultimately bear the choice and consequences of entry, of asylum, of membership, or of the provision of social services directly - becomes the locus of the negotiation of the 'part with no part'. While there are again no guarantees here, the structural opportunity to see the city as a city of refuge is clear. As Manuel Castells eloquently writes:

Thus the historical specificity of European cities may be a fundamental asset in creating the conditions for managing the contradictions between the global and the local in the new context of the informational society. Because European cities have strong civil societies, rooted in an old history and a rich, diversified culture, they could stimulate citizen participation as a fundamental antidote against tribalism and alienation. And because the tradition of European cities as city states leading the place to the modern age in much of Europe is engraved in the collective memory of their people, the revival of the city state could be the necessary complement to the expansion of a global economic and the creation of a European state. ${ }^{171}$

Thus, as Europe searches for new expressions of political legitimacy beyond the present boundaries of the nation-state, the city offers an affirmative counter-model for situating the overlapping and diverse cultures constitutive of contemporary cosmopolitan identity. The city enables political mobilisation beyond the traditional actors in mass representative democracy.

In this respect, droit de cité is not a right to be granted or apportioned or adjudicated from above. Instead, it can only exist, can only be meaningful as a context achieved from below. The inversion is clear. The incursions made against the closed body politic by various immigrant groups or by the populations increasingly pushed to the peripheries of impoverished cities, far from disrupting the polity, these incursions offer precisely the chance (perhaps the first and only in today's globalised world facing the civic appeals of cosmopolitanism) to rebuild active citi-

\footnotetext{
170 See generally Michael Keating \& Monika De Frantz, 'Culture-led Strategies for Urban Regeneration: A Comparative Perspective on Bilbao' (2004) 16(3) International Journal of Iberian Studies 187; Patrick Le Galés, European Cities: Social Conflicts and Governance 261 (OUP 2002).

171 Manuel Castells, 'European Cities, the Informational Society, and the Global Economy' (1994) 204(3-4) New Left Rev 18, 32.
} 
zenship and, with it, a polity in the truest sense of the word, beyond inclusion and exclusion.

Here, the extension of droit de cité anticipates juridical grants of citizenship and political rights. Droit de cité runs before, skips ahead of, the constitutionalisation of rights and their assertion before legal authorities or tribunals. It is in this sense a true moment of founding, when 'time runs widdershins and the present precedes itself', ${ }^{172}$ when the people's contingency is made visible and true political freedom (in the Arendtian sense of beginning something anew) is made possible. As Balibar explains, 'Its indispensable regulations can only result from negotiation and from the recognition of those concerned as legitimate interlocutors who have the right to explain their situation, formulate demands and propose solutions'. ${ }^{173}$ In its anticipation, in its skipping ahead, droit de cité takes on a form similar to the Jacques Derrida's 'democracy-to-come', la démocratie à vénir.

For Derrida, the connection between ethics and politics must signal and affirm one's infinite responsibility to the Other inscribed always provisionally within the finite expressions of self and polity. ${ }^{174}$ Moreover, the task of institutionalising such a relationship is precisely what I take to be the substance of the European project; that is, Europe itself can appropriate the urgency of Derrida's 'The New International', 'another international law, another politics of frontiers, another humanitarian politics', ${ }^{175}$ a 'democracy-to-come'. Elsewhere, Simon Critchley has elaborated the difficulties of the latter term - la démocratie à vénir - and its inherent contradictions, ${ }^{176}$ but the vision is formidable and relevant.

Democracy-to-come in a sense takes place in-between: a glimpsed injunction, an eruption into the here-and-now that, though incalculable, speaks to the calculation of normal politics. It has a dual structure of something yet to occur in the future, while simultaneously 'blasting through the continuum of the present'. ${ }^{177}$ It is the experience, in the end, of the infinite task, for which we will always be held to account, yet the fulfilment of which will always be deferred, as we can fulfil only a limited responsibility ourselves. The movement between the infinite and the finite does resemble a form of process, though very much unlike the

\footnotetext{
172 Fitzpatrick (n 68) 74.

173 Balibar, We, the People of Europe? (n 37) 48.

174 Jacques Derrida, Adieu to Emmanuel Levinas (Michael Naas tr, Stanford UP 1999) 201.

175 ibid 176.

176 See, eg, Simon Critchley, 'The Other's Decision in Me,' Ethics-Politics-Subjectivity: Essays on Derrida, Levinas and Contemporary French Thought 254 (Verso 1999).

177 Simon Critchley, 'Remarks on Derrida and Habermas' (2000) 7(4) Constellations 455, 464.
} 
formal proceduralism of discursive law itself. This movement takes place through a temporal and spatial oscillation, through the recognition of identity as fluid and, in a deep sense, shared - with those who have come before us and with those who will follow.

Droit de cité brings la démocratie à vénir into concrete being; it creates the space for its arrival. If it is to exist at all, European cosmopolitanism requires concrete intervention into identity and difference. It cannot be proclaimed through abstract norms of law and economy. In a sense, cosmopolitanism exists only in the liminal case and must be re-established again and again. Droit de cité is therefore an effort to institutionalise, with all of its risks and uncertainties, a form of civil disobedience, through which the settled constitution can be reassessed, amended, reformulated - specifically by those who are at the margins, in the liminal spaces, those on whom that settled system depends to exist in the first place. ${ }^{178}$ In short, droit de cité calls for the inclusion of the 'part with no part', to democratise the borders of inclusion. In Balibar's terms, the 'minimal' remainder of the human right to have rights becomes the 'maximum' that makes possible the total continuum of rights expected in a democratic community. ${ }^{179}$

It is thereby that - on the path of EU enlargement and integration - we can say with Derrida that we are all Europeans, yet we are also not yet Europeans, and can never wholly be. Indeed, we are European precisely insofar as we see that we are not Europeans fully. The identity of Europe is intertwined with its non-identity, with its non-European Other, and with an openness to an indefinite and unsettled future.

\footnotetext{
178 Balibar writes movingly of the sans-papiers movement in France, of their courage in 'reactivating' a new civic solidarity in the course of challenging the Pasqua and Debre laws of the 1990s. See Balibar, We, the People of Europe? (n 37) 48-9. The heirs of such movements are in some sense the Occupy, 15-M and S21 protests of contemporary Europe.
}

179 ibid 119. 